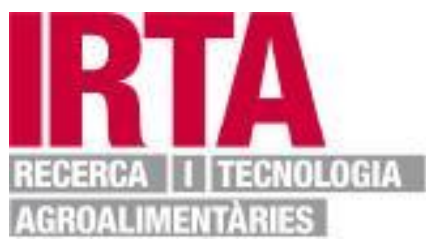

This document is a postprint version of an article published in Meat Science, copyright (C) Elsevier B.V. after peer review.

To access the final edited and published work see:

http://dx.doi.org/10.1016/i.meatsci.2013.12.008 


\title{
High pressure induced changes in beef muscle proteome: correlation with quality parameters
}

\author{
Begonya Marcos ${ }^{1} \&$ Anne Maria Mullen* \\ Teagasc, Ashtown Food Research Centre, Ashtown, Dublin, Ireland.
}

Key words: High pressure processing, sarcoplasmic proteins, myofibrillar proteins, beef quality, protein patterns

* Corresponding author. Teagasc Food Research Centre, Ashtown, Dublin

15, Dublin, Ireland. Tel.: +35318059500.

E-mail address: anne.mullen@teagasc.ie

${ }^{1}$ Author B. Marcos is presently with: IRTA, Food Technology, Finca Camps i Armet, E-17121

Monells, Girona, Spain. begonya.marcos@irta.cat 


\section{Abstract}

2 The relationship between pressure induced changes on individual proteins and selected quality 3 parameters in bovine longissimus thoracis et lumborum (LTL) muscle was studied. Pressures ranging 4 from 200 to $600 \mathrm{MPa}$ at $20^{\circ} \mathrm{C}$ were used. High pressure processing (HPP) at pressures above $200 \mathrm{MPa}$ 5 induced strong modifications of protein solubility, meat colour and water holding capacity (WHC).

6 The protein profiles of non-treated and pressure treated meat were observed using two dimensional 7 electrophoresis. Proteins showing significant differences in abundance among treatments were identified by mass spectrometry. Pressure levels above 200 MPa strongly modified bovine LTL proteome with main effects being insolubilisation of sarcoplasmic proteins and solubilisation of myofibrillar proteins. Sarcoplasmic proteins were more susceptible to HPP effects than myofibrillar. Individual protein changes were significantly correlated with protein solubility, $L^{*}, b^{*}$ and WHC, providing further insights into the mechanistic processes underlying HPP influence on quality and providing the basis for the future development of protein markers to assess the quality of processed meats. 
High pressure processing (HPP) is a non-thermal technology used in the food industry because of its capacity to diminish the microbial load while preserving most of the sensory, nutritional and functional properties of the processed food products (Rivalain, Roquain, \& Demazeau, 2010). Indeed, the meat industry is increasingly adopting this technology as a post-processing technology to extend the shelf life and to improve the safety of ready-to-eat meat products (Cheftel, 1995; Marcos, Aymerich, \& Garriga, 2005; Realini, Guàrdia, Garriga, Pérez-Juan, \& Arnau, 2011). Application of HPP to raw meat has shown to induce colour and texture alterations and thus has not been considered appropriate as an industrial practice (Carlez, Veciana-Nogues, \& Cheftel, 1995; Cheftel \& Culioli, 1997; McArdle, Marcos, Kerry, \& Mullen, 2011). However, HPP has been proposed as a possible way of improving the functional properties of muscle proteins in processed meat (Jimenez Colmenero, 2002; Macfarlane \& McKenzie, 1976; Messens, Van Camp, \& Huyghebaert, 1997). High pressure can affect protein conformation and can lead to protein denaturation, aggregation or gelation (Cheftel \& Culioli, 1997; Gross \& Jaenicke, 1994; Picouet et al., 2012). The outcome is dependent upon protein susceptibility, the applied pressure and temperature, and the duration of the pressure treatment (Sun \& Holley, 2010).

The effects of HPP on proteins are mainly related to the rupture of non-covalent interactions within protein molecules (Galazka, Sumner, \& Ledward, 1996). Covalent bonds and primary structures of the proteins are thought not to be affected by high pressure (Heremans \& Smeller, 1998). Pressure induced denaturation of proteins is likely to occur because of the destabilisation of non-covalent interactions in the tertiary structure (Chapleau, Mangavel \& Lamballerie-Anton, 2004). Even if pressurised proteins retain most of their secondary structure, a small degree of unfolding occurs, which exposes hydrophobic regions of the protein and can lead to protein aggregation (Cheftel \& Culioli, 1997; Sikes, Tornberg, \& Tume, 2010). Sikes et al. (2010) have proposed that in complex, composite structures like meat, consisting of water, lipids and numerous individual soluble and fibrous proteins, dissociation of protein aggregates on high pressure treatment can lead to the solubilisation of proteins. That can, in turn, be initiated by the breakage of salt bonds and/or hydrophobic bonding.

Considering the effect of HPP on meat proteins, it is important to further investigate these effects to better understand its impact on meat quality. Previous observations by the authors suggested the relationship between changes in sarcoplasmic proteins and alteration of meat quality in beef longissimus thoracis et lumborum (LTL) muscle pressurised in a range of 200-600 MPa (Marcos, Kerry, \& Mullen, 2010). The authors reported the relationship between modification of the sarcoplasmic 
studies have dealt with the effects of HPP on specific proteins or protein fractions (Chapleau \& Lamballerie, 2003; Lee, Kim, Lee, Hong, \& Yamamoto, 2007; Macfarlane, McKenzie, \& Turner, 1986; Sikes et al., 2010). However, to our knowledge, no reports characterising the effects of high pressure processing on both sarcoplasmic and myofibrillar extracts with further identification of the proteins affected by HPP are available. Therefore, the aim of this study was to identify pressure induced changes in the LTL proteome and to analyse their relationship with alterations in selected meat quality parameters in order to better understand the effect of HPP on the proteome and gain further insights into how this impacts on quality.

\section{Materials and Methods}

Sample preparation and High Pressure Processing (HPP)

Beef LTL muscles were obtained from a local Irish distributor. Briefly, carcasses from 3 crossbred heifers slaughtered at 24 months of age were hip hung within 1 hour of slaughter for 3 days. Muscles were excised, individually vacuum packed and stored at $4^{\circ} \mathrm{C}$ until sampling. At 7 days post-mortem muscles were cut into $2.5 \times 2.5 \times 3 \mathrm{~cm}$ pieces. From each muscle a $300 \mathrm{~g}$ portion of meat pieces was vacuum packed in polyamide polyethylene bags and randomly assigned to each treatment. Meat samples were treated in an industrial pressurisation unit Model Wave 6000 (Hyperbaric, Burgos, Spain), with a vessel volume of $120 \mathrm{I}$. HPP was performed at 200, 400 and $600 \mathrm{MPa}$ for $20 \mathrm{~min}$ at $20^{\circ} \mathrm{C}$. A $300 \mathrm{~g}$ portion was also taken from each muscle for a non-treated (NT) control. Each treatment was carried out in triplicate (i.e. meat from an individual animal equates to one replicate). Meat portions were allowed to cool down at room temperature for $30 \mathrm{~min}$ after high pressure processing, cut into individual pieces for each analysis, vacuum packed and frozen at $-80^{\circ} \mathrm{C}$. Samples were transported on dry ice to Teagasc Ashtown (Dublin, Ireland) for subsequent analysis. Samples for proteomic analysis were used directly from frozen and samples for quality analysis were thawed at $4^{\circ} \mathrm{C}$ for $12 \mathrm{~h}$ before analysis.

\section{Colour measurement}

The internal colour of non-treated and pressurised samples was measured on a transversal section of the meat using a HunterLab spectrophotometer (Ultrascan XE, Hunter Associates Laboratory, Inc., Reston, VA), with a D65 illuminant, $10^{\circ}$ standard observer angle and $25 \mathrm{~mm}$ port size. Freshly cut samples were allowed to bloom for 20 min prior to analysis. Colour coordinates were determined using the 1976 CIELAB system and the results were expressed as L* (lightness), a* (redness) and b* (yellowness). The instrument was calibrated before each series of measurements using white $\left(L^{*}=\right.$ 100) and black $\left(L^{*}=0\right)$ standard tiles. Colour measurements were taken at three locations on each 
sample and averaged. The total colour difference $(\Delta E)$ was determined as an estimate of colour changes. $\Delta E$ was calculated as suggested by Jung, Ghoul \& de Lamballerie-Anton (2003):

$\Delta E=\left[\left(\mathrm{L}^{*}-\mathrm{L}_{0} *\right)^{2}+\left(\mathrm{a}^{*}-\mathrm{a}_{0} *\right)^{2}+\left(\mathrm{b}^{*}-\mathrm{b}_{0}{ }^{*}\right)^{2}\right]^{1 / 2}=\left[\left(\Delta \mathrm{L}^{*}\right)^{2}+\left(\Delta \mathrm{a}^{*}\right)^{2}+\left(\Delta \mathrm{b}^{*}\right)^{2}\right]^{1 / 2}$

The colour values of non-treated samples $\left(\mathrm{L}_{0}{ }^{*}, \mathrm{a}_{0}{ }^{*}, \mathrm{~b}_{0}{ }^{*}\right)$ were used as reference values for $\Delta E$ calculation.

\section{Expressible moisture}

Expressible moisture (EM) was determined with a centrifugal method according to Pietrasik \& Shand (2004) with some modifications. Meat samples $(1.5 \times 1.5 \times 2.5 \mathrm{~cm})$ of known weight $(3.5 \pm 0.2 \mathrm{~g})$ were placed in $50 \mathrm{ml}$ centrifuge tubes lined with a thimble consisting of Whatman No. 3 filter paper folded around Whatman No. 50 filter paper. Samples were centrifuged at 5,000 rpm for $20 \mathrm{~min}$ at $4^{\circ} \mathrm{C}$. EM was expressed as the percentage of moisture loss after centrifugation in relation to the initial sample weight.

\section{Extraction of muscle proteins}

Meat pieces of approximately $5 \mathrm{~g}$ were ground in a cryogenic freezer mill (SPEX CertiPrep, Inc., Metuchen, NJ, USA). Sarcoplasmic proteins were extracted from $2 \mathrm{~g}$ of pulverised muscle homogenised in $6 \mathrm{ml}$ of extraction buffer ( $\mathrm{pH}$ 7.6) containing $20 \mathrm{mM}$ TRIS, $2 \mathrm{mM}$ EDTA, $4 \mathrm{mM} \mathrm{MgCl}$ and $10 \mu \mathrm{l} / \mathrm{ml}$ protease inhibitor mix (GE Healthcare, Uppsala, Sweden). Homogenates were centrifuged at $14,000 \mathrm{rpm}$ for $20 \mathrm{~min}$ at $4^{\circ} \mathrm{C}$. Supernatants containing sarcoplasmic proteins were removed and frozen at $-80^{\circ} \mathrm{C}$ until further analysis. The pellet was washed three times with distilled water and re-suspended in a denaturing solution (7 M urea, $2 \mathrm{M}$ thiourea $2 \%$ CHAPS, $0.8 \%$ Pharmalyte broad range pH 3-10 (GE Healthcare), and 1\% DTT). Homogenates were centrifuged at $7,000 \mathrm{rpm}$ for $45 \mathrm{~min}$ at $20^{\circ} \mathrm{C}$. Supernatants containing myofibrillar proteins were removed after centrifugation and frozen at $-80^{\circ} \mathrm{C}$ until further analysis.

Protein concentrations were determined using the Bio-Rad Protein Assay Kit (Bio-Rad Laboratories, Hercules, CA, USA) based on the Bradford method (Bradford, 1976). Bovine serum albumin was used as the standard. Sarcoplasmic and myofibrillar protein solubility were expressed as $\mu \mathrm{g}$ protein/g meat. Total protein solubility was calculated as the sum of sarcoplasmic and myofibrillar protein solubility of each sample.

\section{Two dimensional electrophoresis (2DE)}

Muscle proteins were separated by 2D-electrophoresis (2DE). Nine hundred $\mu \mathrm{g}$ of either sarcoplasmic or myofibrillar proteins was included in a buffer containing 7M urea, $2 \mathrm{M}$ thiourea, $2 \%$ CHAPS, $0.3 \%$ DTT, 1\% Pharmalyte pH 3-10, and traces of bromophenol blue. Samples were loaded onto 
120 immobilised $\mathrm{pH}$ gradient strips ( $\mathrm{pH} 4-7,24 \mathrm{~cm}, \mathrm{GE}$ Healthcare) that were rehydrated for $16 \mathrm{~h}$. 121 Isoelectric focusing (IEF) was performed using an Ettan IPHphor 3 IEF Unit (GE Healthcare). The 122 voltage was applied as follows: step 1, $500 \mathrm{~V}$ for $1 \mathrm{~h}$; step 2, 3,500 V until 75,000 Vh were reached; 123 step 3, 8,000 V for $1 \mathrm{~h}$. After IEF, the strips were equilibrated for $15 \mathrm{~min}$ at room temperature in $10 \mathrm{ml}$ 124 of equilibration buffer $(50 \mathrm{mM}$ Tris- $\mathrm{HCl}$ pH 8.8, 6M urea, $30 \%$ Glycerol, $2 \%$ SDS, and traces of 125 bromophenol blue) with $1 \%$ DTT $(\mathrm{w} / \mathrm{v})$ added immediately before use. After removing the DTT 126 solution, the strips were equilibrated for $15 \mathrm{~min}$ at room temperature in $10 \mathrm{ml}$ of equilibration buffer 127 with $2.5 \%$ of iodoacetamide added immediately before use. In the second dimension, proteins were resolved on 12\% SDS-PAGE gels using a Protean plus Dodeca Cell system (BioRad). The gels were fixed with $50 \%$ ethanol and $2 \%$ phosphoric acid for $3 \mathrm{~h}$ with gentle shaking. After removing the fixing solution, the gels were washed three times in distilled water for $20 \mathrm{~min}$. The gels were stained with $660 \mathrm{mg} / \mathrm{l}$ of colloidal Coomassie Brilliant Blue G-250 (Sigma-Aldrich, St. Louis, MO, USA) in 3\%

132 phosphoric acid, 17 ammonium persulfate, and 34\% methanol for 5 days with gentle shaking. Two

133 technical replicates were obtained for each sample. Image analysis

136 Gel images were acquired using a GS-800 densitometer (BioRad) and analysed using Progenesis 137 Samespots version 3.2 software (Nonlinear Dynamics, Durham, NC, USA). Briefly, the gel image with 138 the most spots detected was assigned as a reference, and all remaining gel images were aligned to 139 this reference gel. Gel alignment was verified manually after automatic alignment. Landmark spots 140 were used to confirm spot matching across all gels and manual verification was used to screen out 141 any dust artefacts or incorrectly identified spots. The normalised volume for each spot on each gel 142 was calculated with the software. Log transformation of the spot volumes was used to generate 143 normally distributed data. Log normalised volume was used to compare spot abundance. Significant 144 differences among treatments were evaluated by summarising the number of spots in the comparative proteomic studies with $\mathrm{p}<0.05$, 2-fold increase, and $\mathrm{q}<0.01$.

148 Proteins were subjected to in-gel protein digestion. Excised gel spots were destained with $70 \mu$ l of $149200 \mathrm{mM} \mathrm{NH}_{4} \mathrm{HCO}_{3}$ with shaking for $10 \mathrm{~min}$ at $37^{\circ} \mathrm{C}$. After centrifugation, the solution was removed. 150 Then, $70 \mu \mathrm{l} 200 \mathrm{mM} \mathrm{NH}_{4} \mathrm{HCO}_{3}$ /acetonitrile (2:3) were added. After shaking for 10 minutes at $37^{\circ} \mathrm{C}$ and 151 centrifugation, the solution was removed. Addition of $70 \mu \mathrm{l}$ of $50 \mathrm{mM} \mathrm{NH}_{4} \mathrm{HCO}_{3}$ was followed by 152 shaking for $10 \mathrm{~min}$ at $37^{\circ} \mathrm{C}$. After centrifugation, the solution was removed. Finally, $70 \mu \mathrm{l}$ of 153 acetonitrile was added to each tube and shaken for 10 minutes at $37^{\circ} \mathrm{C}$. After removal of the 
solution, gel spots were incubated with $200 \mathrm{mM}$ ammonium bicarbonate for $20 \mathrm{~min}$; this step was repeated until they become colourless. The gel pieces were rehydrated with $30 \mu \mathrm{l}$ of $50 \mathrm{mM}$ ammonium bicarbonate containing $0.2 \mu \mathrm{g}$ of trypsin (Promega, Madison, WI, USA) and digestion was performed overnight with shaking at $37^{\circ} \mathrm{C}$. The supernatant was then dried down in a vacuum centrifuge (Eppendorf Concentrator 5301, Hamburg, Germany) at 45ㄷ.

Thermo Scientific LTQ ORBITRAP XL mass spectrometer connected to an Exigent NANO LC.1DPLUS chromatography system incorporating an auto-sampler was used for analysis. Tryptic peptides were resuspended in $0.1 \%$ formic acid. Each sample was loaded onto a Biobasic C18 Picofrit ${ }^{\mathrm{TM}}$ column (100 $\mathrm{mm}$ length, $75 \mathrm{~mm}$ ID) and was separated by an increasing acetonitrile gradient, using a $25 \mathrm{~min}$ reverse phase gradient $(0-50 \%$ acetonitrile for $11 \mathrm{~min})$ at a flow rate of $30 \mathrm{nl} / \mathrm{min}$. The mass spectrometer was operated in positive ion mode with a capillary temperature of $200^{\circ} \mathrm{C}$, a capillary voltage of $9 \mathrm{~V}$, a tube lens voltage of $100 \mathrm{~V}$ and with a potential of $1800 \mathrm{~V}$ applied to the frit. All data was acquired with the mass spectrometer operating in automatic data dependent switching mode. A high resolution MS scan (300-2000 Dalton) was performed using the Orbitrap to select the five most intense ions prior to MS/ MS analysis using the lon trap. The search was done using TurboSEQUEST (Bioworks Browser 3.3.1 SP1; Thermo Finnigan, UK) searching the bovine subset of the Uniprot /Swissprot fasta database for fully and partially tryptic peptides. Each peptide used for protein identification met specific SEQUEST parameters, i.e. cross-correlation values $\geq 1.9, \geq 2.5, \geq 3.2$ and $\geq 3.2$ for single-, double-, triple- and quadruple-charged peptides, respectively.

\section{Statistical analysis}

Data obtained from the quality analysis were analysed using the General Linear Model from SAS (version 9.2, SAS Institute, Cary, NC, USA). The treatment (NT, $200 \mathrm{MPa}, 400 \mathrm{MPa}$, and $600 \mathrm{MPa}$ ) was included in the model as a fixed effect, with animal as a random effect. Differences between means were assessed by the Tukey test $(p<0.05)$. Pearson correlation analysis was used to investigate the relationship among quality indicators and spot intensities. Correlation coefficients were calculated with the CORR procedure of SAS 9.2. A multiple testing correction consisting of a modification of the effective number (Cheverud, 2001) was performed as suggested by Li and Ji (2005).

\section{Results and discussion}

184 Impact of HPP on meat quality

185 Table 1 shows the effect of high pressure processing on protein solubility of bovine LTL. 186 Pressurisation of beef samples induced a reduction of total protein solubility which seemed to be 187 explained by changes in the sarcoplasmic fraction $(p<0.001)$, with the exception of HPP at $200 \mathrm{MPa}$ 188 (Table 1). Processing above this pressure level induced an increasing loss of protein solubility as the 
pressure level increased. HPP had no effect $(p>0.05)$ on myofibrillar protein solubility. This fact was confirmed by the correlation analysis which showed a strong positive correlation between total and 191 sarcoplasmic protein solubility (Table 2). A reduction of muscle protein solubility is an indicator of 192 protein denaturation as solubility decreases due to the formation of insoluble protein aggregates 193 that can no longer be extracted (Fischer, Hamm, \& Honikel, 1979; Laakkonen, Sherbon, \& Wellington, 194 1970). Thus, the decreased protein solubility observed suggests certain sarcoplasmic protein denaturation induced by exposure to pressures above $200 \mathrm{MPa}$. Pressure induced denaturation would lead to the formation of aggregates, most probably generated through intermolecular disulfide bridges (Galazka, Dickinson, \& Ledward, 2000). These results agree with previous observations reporting reduction of sarcoplasmic protein solubility in pressurised beef (Kim, Lee, Lee, Kim, \& Yamamoto, 2007; Marcos et al., 2010). Differing effects of HPP on the solubility of myofibrillar proteins, either solubilisation or insolubilisation, have been observed depending on the protein under study (Chan, Omana, \& Betti, 2011; Chapleau \& Lamballerie, 2003; Iwasaki, Noshiroya, Saitoh, Okano, \& Yamamoto, 2006; Sikes, Tobin, \& Tume, 2009).

The water holding capacity (WHC) of beef muscle was calculated by means of the expressible moisture (EM), which measures the percentage of moisture loss of the meat under specific conditions. Pressurisation at $200 \mathrm{MPa}$ had no impact on EM of beef, while samples at 400 and 600 MPa showed increased EM compared to NT beef (Table 1). This result indicates a reduction of WHC of beef at the higher pressure levels. Kim et al. (2007) reported a similar reduction in WHC of bovine semitendinosus muscle treated at 400-500 MPa, although they also reported decreased WHC at 200 MPa. Fernández et al. (2007) also reported higher EM in beef pressurised at $650 \mathrm{MPa}$. Myofibrillar proteins, myosin and actin, and to some extent tropomyosin are known as the main water-binding components in muscle tissue (Zayas, 1997). Some authors have highlighted the important role of sarcoplasmic proteins in determining WHC of meat (Joo, Kauffman, Kim, \& Park, 1999; Monin \& Laborde, 1985) and its presence in the centrifugal drip (Di Luca, Mullen, Elia, Davey, \& Hamill, 2011). Moreover, precipitation of sarcoplasmic proteins on the myofibrils has been suggested as a possible cause of the loss of water binding capacity in meats with altered water retention properties (LopezBote \& Warriss, 1988; Monin \& Laborde, 1985). In this sense, a negative correlation $(p<0.01)$ between sarcoplasmic protein solubility and expressible moisture was observed (Table 2), confirming the relationship between pressure induced denaturation of sarcoplasmic proteins and the loss of

220 Pressurised meat experienced a significant increase of L* (lightness) compared to non-treated meat 221 (Table 1). Samples pressurised at $400 \mathrm{MPa}$ and $600 \mathrm{MPa}$ showed the highest $\mathrm{L}^{*}$ values. Increased 222 lightness of meat is a well documented result of pressurisation of red muscles (Carlez et al., 1995; 223 Goutefongea, Rampon, Nicolas, \& Dumont, 1995; McArdle, Marcos, Mullen, \& Kerry, 2013; Serra et 
al., 2007; Shigehisa, Ohmori, Saito, Taji, \& Hayashi, 1991). The whitening effect induced by pressure

225 has been related to protein coagulation, which would affect sample structure and surface properties 226 (Goutefongea, Rampon, Nicolas, \& Dumont, 1995), and to globin denaturation and heme group 227 displacement or release (Carlez et al., 1995). HPP did not alter the redness ( $\left.a^{*}\right)$ of the meat $(p>0.05)$. 228 An increase in yellowness $\left(b^{*}\right)$ compared to NT samples was observed at pressures above $200 \mathrm{MPa}$. 229 Higher $b^{*}$ values obtained at 400 and $600 \mathrm{MPa}$ agree with the brownish colouration of meat 230 observed at these pressures, and could be related to the pressure induced oxidation of ferrous 231 myoglobin to ferric metmyoglobin (Carlez et al., 1995). The total colour difference $(\Delta E)$ was 232 determined as an estimate of colour changes in pressurised meat. HPP at 400 and $600 \mathrm{MPa}$ induced 233 more pronounced colour changes compared to $200 \mathrm{MPa}$ (Table 1). It has been suggested that a 234 change of 10 units in $\Delta \mathrm{E}$ would be considered to significantly modify meat appearance (Jung et al., 235 2003). According to that, it can be concluded that HPP at $200 \mathrm{MPa}$, with $\Delta \mathrm{E}$ lower than 10, slightly 236 modified meat appearance. On the contrary, more severe treatments (400 \& $600 \mathrm{MPa}$ ) strongly 237 modified meat appearance. This result agrees with previous observations by Marcos et al. (2010). It 238 should be noted that stronger modifications observed at higher pressure levels might be also 239 influenced by a higher adiabatic heating with increasing pressure levels.

240 Correlations of colour coordinates with other quality parameters showed that pressure induced 241 changes in protein solubility and EM were both associated with changes in $\mathrm{L}^{*}$ and $\mathrm{b}^{*}$ coordinates 242 (Table 2). Several authors have suggested a relationship between increased meat lightness and 243 precipitation of sarcoplasmic proteins (Goutefongea et al., 1995; Joo et al., 1999; McLoughlin \& 244 Goldspink, 1963; van Laack et al., 1994).

Influence of HPP on bovine protein profiles

247 The protein profiles of non-treated (NT) and pressurised (200, $400 \& 600 \mathrm{MPa}$ ) beef LTL were 248 obtained with 2-DE. Figure 1 shows two representative 2-DE gels showing the effects of HPP on 249 sarcoplasmic protein profiles. After removal of false positives and saturated or poorly reducible zones, 988 spots were successfully matched across the whole set of gel images. In order to assess in detail the differences among treatments, variations in protein expression were quantified by statistically comparing relative spot intensities. A total of 44 spots were differentially represented among the studied treatments ( $p<0.01$ and 2 -fold increase). From these, 37 spots were successfully identified with MS (Table 3). The protein spots showing differences in abundance among treatments were mainly sarcoplasmic proteins, although 11 protein spots corresponded to myofibrillar proteins.

256 The effect of HPP on protein abundance was different depending on the type of protein. In the 257 sarcoplasmic fraction HPP increased the amount of myofibrillar proteins present while decreasing 258 the amount of sarcoplasmic proteins (Table 3). HPP at the lowest pressure level (200 MPa) had little 
effect on the sarcoplasmic protein profile. Among sarcoplasmic proteins, the most pressure labile 260 were cytosol aminopeptidase, glycerol-3-phosphate dehydrogenase [NAD+], and glycogen 261 phosphorylase, which experienced losses at $200 \mathrm{MPa}$. On the contrary, the most pressure resistant 262 sarcoplasmic proteins were heat shock $70 \mathrm{kDa}$ protein $1 \mathrm{~A}$, malate dehydrogenase, retinal 263 dehydrogenase 1 , and serotransferrin, which decreased only after HPP at $600 \mathrm{MPa}(\mathrm{p}<0.01)$. On the other hand, the presence of myofibrillar protein fragments present in the soluble fraction (myosin light chain 1, tropomyosin $\alpha-1$ chain, tropomyosin $\beta$-chain, troponin $T$, fast and slow skeletal muscle) increased due to HPP at pressures above $200 \mathrm{MPa}$ (Table 3).

Figure 2 shows two representative 2-DE gels of the myofibrillar protein fraction extracted from nonpressurised and pressurised beef. A total of 954 protein spots were included in the statistical analysis. Fifty six spots showed differences among treatments ( $p<0.01$ and 2 -fold increase). From these, 52 spots were successfully identified by MS (Table 4). As previously reported, the effect of HPP was dependent on the type of protein. HPP induced a decrease of the abundance of myofibrillar 272 proteins, while increasing the abundance of sarcoplasmic proteins in the myofibrillar fraction (Table 4). HPP at $200 \mathrm{MPa}$ had little effect on the protein profile. The proteins in the myofibrillar fraction showing differences in abundance among treatments were mainly sarcoplasmic proteins. Only six myofibrillar protein spots were affected by HPP and were identified as actin, F-actin-capping protein, tropomyosin $\alpha-1$ and $\beta$ chain, and tubulin $\beta-2 B$ chain (in two separate spots). Among the sarcoplasmic proteins in the myofibrillar extract, flavin reductase, glycerol-3-phosphate dehydrogenase $\left[\mathrm{NAD}^{+}\right]$, heat shock 70KDa protein $1 \mathrm{~A}$, actin and tropomyosin $\beta$ chain were the only proteins altered at $200 \mathrm{MPa}$. The highest pressure level applied (600 MPa) was necessary to modify the presence of $\alpha$-enolase, malate dehydrogenase, peptide methionine sulfoxide reductase, serotrasferrin, and serum albumin content in the myofibrillar protein fraction (Table 4). In agreement with our results several authors have reported pressure induced changes in the sarcoplasmic protein fraction of meat due to HPP, with a stronger effect as the pressure of the treatment increased, mainly above 200MPa (Angsupanich \& Ledward, 1998; Cheah \& Ledward, 1996; Cheret, Hernandez-Andres, Delbarre-Ladrat, Lamballerie, \& Verrez-Bagnis, 2006). Cheah and Ledward (1996) attributed the decreased sarcoplasmic band intensities to protein degradation or insolubilisation due to denaturation and aggregation of proteins. However, Ohshima, Ushio, and Koizumi (1993) suggested that rather than being degraded by HPP, certain fish sarcoplasmic proteins become covalently linked together. Pressure induces the disruption of hydrophobic and electrostatic interactions while enhancing hydrogen bonding as well as promoting formation of disulphide bonds (Mozhaev, Heremans, Frank, Masson, \& Balny, 1994). Our results would confirm the insolubilisation of sarcoplasmic proteins which were extracted together with the myofibrillar protein fraction after HPP. To our knowledge, this is the first study reporting the effects of HPP on individual sarcoplasmic 
proteins. Most investigations have focused on pressure induced changes in the myofibrillar protein

295 fraction. Several authors have observed the solubilisation of myofibrillar proteins due to HPP (Cheah

296 \& Ledward, 1996; Jung, de Lamballerie-Anton, \& Ghoul, 2000; Sikes et al., 2009). Increased solubility

297 of myofibrillar proteins due to HPP has been related to protein depolymerisation and subsequent 298 increased interactions between protein constituents and water (Cheftel \& Culioli, 1997). Similarly to 299 our results, other authors have reported pressure induced solubilisation of myosin light chains, 300 tropomyosin, troponin T, and actin (Angsupanich, Edde, \& Ledward, 1999; Iwasaki et al., 2006; Jung et al., 2000; Ma, Zhou, Ledward, Yu, \& Pan, 2011; McArthur \& Wilding, 1996). Solubilisation of $\alpha$ actinin, troponin C and M-protein and C-protein has also been reported (Iwasaki et al., 2006; Lee et al., 2007; Ma et al., 2011).

Relationship between protein abundance and meat quality traits

Tables 5 and 6 show the significant correlations between meat quality traits and the spot volume of the proteins that were affected by HPP. In the sarcoplasmic protein fraction a negative correlation between sarcoplasmic protein abundance and $L^{*}, b^{*}, \triangle E$ and $E M$ was observed, while myofibrillar proteins were positively correlated $(p<0.006)$. For the myofibrillar extracts, the correlations were inversed, a positive correlation between sarcoplasmic protein abundance and $L^{*}, b^{*}, \Delta E$ and $E M$ was observed, while myofibrillar proteins presented a negative correlation with the studied quality parameters $(p<0.005)$. On the contrary, no correlations were found between protein spot volumes and meat redness ( $\left.a^{*}, p>0.05\right)$. These data indicate that pressure induced solubilisation of myofibrillar proteins and insolubilisation of sarcoplasmic proteins resulted in paler meat with decreased WHC. These results reflect the impact of pressure induced changes on proteome profiles, mainly on sarcoplasmic proteins, and on meat quality parameters. These results would confirm the strong role of sarcoplasmic protein fraction on meat quality previously suggested by the authors (Marcos et al., 2010). Similarly, other authors have highlighted the role of sarcoplasmic proteins such as aldehyde dehydrogenase, glycerol-3-Pdehydrogenase, protein DJ-1, serotransferrin, $\beta$-enolase, creatine kinase $M$-type and heat shock protein 70 kDa on meat L* and drip loss (Hwang, Park, Cho, \& Lee, 2004; Kwasiborski et al., 2008; Sayd et al., 2006; van de Wiel \& Zhang, 2007). As expected, total protein solubility was strongly correlated with protein abundance. However, looking into each protein fraction, no correlation with myofibrillar protein solubility was observed ( $p>0.05)$.

327 Data from this study indicate that HPP at pressure levels above $200 \mathrm{MPa}$ strongly modified the 328 protein profiles and the quality parameters of bovine longissimus thoracis et lumborum muscle. HPP 
induced strong changes in protein solubility suggesting that monitoring of protein solubility in

330 processed meats can provide an indication of meat quality.

331 The proteins that were more affected by HPP were the sarcoplasmic proteins in the range of 332 molecular weights and isoelectric points covered by this study. The relationship between changes at 333 the proteome levels and changes in meat quality provide further insights into the mechanistic processes underlying HPP influence on quality and may provide the basis for the development of protein markers to assess the quality of processed meats.

\section{Acknowledgements}

338 The authors would like to thank Narcís Grèbol from CENTA (Monells, Spain) and Caitriona Scaife from 339 UCD Conway Institute for their assistance. This research was funded under the Irish National 340 Development Plan under the Food Institutional Research Measure, administered by the Department of Agriculture, Fisheries and Food.

\section{References}

Angsupanich, K., Edde, M., \& Ledward, D. A. (1999). Effects of High Pressure on the Myofibrillar Proteins of Cod and Turkey Muscle. J. Agric. Food Chem., 47(1), 92-99.

Angsupanich, K., \& Ledward, D. A. (1998). High pressure treatment effects on cod (Gadus morhua) muscle. Food Chemistry, 63(1), 39-50.

Bradford, M. M. (1976). A rapid and sensitive method for the quantitation of microgram quantities of protein utilizing the principle of protein-dye binding. Analytical Biochemistry, 72, 248-254.

Carlez, A., Veciana-Nogues, T., \& Cheftel, J. C. (1995). Changes in colour and myoglobin of minced beef meat due to high pressure processing. Lebensmittel-Wissenschaft und-Technologie, 28(5), 528-538.

Chan, J. T. Y., Omana, D. A., \& Betti, M. (2011). Application of high pressure processing to improve the functional properties of pale, soft, and exudative (PSE)-like turkey meat. Innovative Food Science \&amp; Emerging Technologies, 12(3), 216-225.

Chapleau, N., \& Lamballerie, M. (2003). Changes in myofibrillar proteins interactions and rheological properties induced by high-pressure processing. European Food Research and Technology, $216,470-476$.

Chapleau, N., Mangavel, C., J.P., C., \& Lamballerie-Anton, M. (2004). Effect of high-pressure processing on myofibrillar protein structure. Journal of the Science of Food and Agriculture, 84(1), 66-74.

Cheah, P. B., \& Ledward, D. A. (1996). High pressure effects on lipid oxidation in minced pork. Meat Science, 43(2), 123-134.

Cheftel, J. C. (1995). Review: High-pressure, microbial inactivation and food preservation. Food Science and Technology International, 1, 75-90.

Cheftel, J. C., \& Culioli, J. (1997). Effects of high pressure on meat: a review. Meat Science, 46(3), $211-$ 236.

Cheret, R., Hernandez-Andres, A., Delbarre-Ladrat, C., Lamballerie, M., \& Verrez-Bagnis, V. (2006). Proteins and proteolytic activity changes during refrigerated storage in sea bass (Dicentrarchus labrax L.) muscle after high-pressure treatment. European Food Research and Technology, 222(5-6), 527-535. 
Cheverud, J. M. (2001). A simple correction for multiple comparisons in interval mapping genome scans. Heredity, 87, 52-58.

Di Luca, A., Mullen, A. M., Elia, G., Davey, G., \& Hamill, R. M. (2011). Centrifugal drip is an accessible source for protein indicators of pork ageing and water-holding capacity. Meat Science, 88(2), 261-270.

Fernández, P. P., Sanz, P. D., Molina-García, A. D., Otero, L., Guignon, B., \& Vaudagna, S. R. (2007). Conventional freezing plus high pressure-low temperature treatment: Physical properties, microbial quality and storage stability of beef meat. Meat Science, 77(4), 616-625.

Fischer, C., Hamm, R., \& Honikel, K. O. (1979). Changes in solubility and enzymic activity of muscle glycogen phosphorylase in PSE-muscles. Meat Science, 3(1), 11-19.

Galazka, V. B., Dickinson, E., \& Ledward, D. A. (2000). Influence of high pressure processing on protein solution and emulsions. Current Opinion in Colloid and Interface Science, 5, 182-187.

Galazka, V. B., Sumner, I. G., \& Ledward, D. A. (1996). Changes in protein-protein and proteinpolysaccharide interactions induced by high pressure. Food Chemistry, 57(3), 393-398.

Goutefongea, R., Rampon, V., Nicolas, J., \& Dumont, J. P. (1995). Meat color changes under high pressure treatment. In 41st International Congress of Meat Science and Technology (Vol. II, pp. 384-385). San Antonio, Texas: Am. Meat Sci. Assoc.

Gross, M., \& Jaenicke, R. (1994). Proteins under pressure. The influence of high hydrostatic pressure on structure, function and assembly of proteins and protein complexes. European Journal of Biochemistry, 221, 617-630.

Heremans, K., \& Smeller, L. (1998). Protein structure and dynamics at high pressure. Biochimica et Biophysica Acta, 1386, 353-370.

Hwang, I. H., Park, B. Y., Cho, S. H., \& Lee, J. M. (2004). Effects of muscle shortening and proteolysis on Warner-Bratzler shear force in beef longissimus and semitendinosus. Meat Science, 68(3), 497-505.

Iwasaki, T., Noshiroya, K., Saitoh, N., Okano, K., \& Yamamoto, K. (2006). Studies of the effect of hydrostatic pressure pretreatment on thermal gelation of chicken myofibrils and pork meat patty. Food Chemistry, 95(3), 474-483.

Jimenez Colmenero, F. (2002). Muscle protein gelation by combined use of high pressure/temperature. Trends in Food Science \& Technology, 13(1), 22-30.

Joo, S. T., Kauffman, R. G., Kim, B. C., \& Park, G. B. (1999). The relationship of sarcoplasmic and myofibrillar protein solubility to colour and water-holding capacity in porcine longissimus muscle. Meat Science, 52(3), 291-297.

Jung, S., de Lamballerie-Anton, M., \& Ghoul, M. (2000). Modifications of Ultrastructure and Myofibrillar Proteins of Post-rigor Beef Treated by High Pressure. Lebensmittel-Wissenschaft und-Technologie, 33(4), 313-319.

Jung, S., Ghoul, M., \& de Lamballerie-Anton, M. (2003). Influence of high pressure on the color and microbial quality of beef meat. Lebensmittel-Wissenschaft und-Technologie, 36(6), 625-631.

Kim, I. J., Lee, E. J., Lee, N. H., Kim, Y. H., \& Yamamoto, K. (2007). Effects of hydrostatic pressure treatment on the physicochemical, morphological, and textural properties of bovine Semitendinosus muscle. Food Science and Biotechnology, 16(1), 49-54.

Kwasiborski, A., Sayd, T., Chambon, C., Santé-Lhoutellier, V., Rocha, D., \& Terlouw, C. (2008). Pig Longissimus lumborum proteome: Part II: Relationships between protein content and meat quality. Meat Science, 80(4), 982-996.

Laakkonen, E., Sherbon, J. W., \& Wellington, G. H. (1970). Low-temperature, long-time heating of bovine muscle: 2. Changes in electrophoretic patterns. Journal of Food Science, 35, 178-180.

Lee, E.-J., Kim, Y.-J., Lee, N.-H., Hong, S.-I., \& Yamamoto, K. (2007). Differences in properties of myofibrillar proteins from bovine semitendinosus muscle after hydrostatic pressure or heat treatment. Journal of the Science of Food and Agriculture, 87(1), 40-46.

$\mathrm{Li}, \mathrm{J} .$, \& Ji, L. (2005). Adjusting multiple testing in multilocus analysis using the eigenvalues of a correlation matrix. Heredity, 95, 221-227. 
Lopez-Bote, C., \& Warriss, P. D. (1988). A note on the relationships between measures of water holding capacity in the M. Longissimus dorsi and total drip loss from butchered pig carcasses during storage. Meat Science, 23(3), 227-234.

Ma, H., Zhou, G., Ledward, D. A., Yu, X., \& Pan, R. (2011). Effect of Combined High Pressure and Thermal Treatment on Myofibrillar Proteins Solubilization of Beef Muscle. International Journal of Molecular Sciences, 12(5), 3034-3041.

Macfarlane, J. J., \& McKenzie, I. J. (1976). Pressure-induced solubilization of myofibrillar proteins. Journal of Food Science, 41(6), 1442-1446.

Macfarlane, J. J., McKenzie, I. J., \& Turner, R. H. (1986). Pressure-heat treatment of meat: Changes in myofibrillar proteins and ultrastructure. Meat Science, 17(3), 161-176.

Marcos, B., Aymerich, T., \& Garriga, M. (2005). Evaluation of high pressure processing as an additional hurdle to control Listeria monocytogenes and Salmonella enterica in low-acid fermented sausages. Journal of Food Science, 70(7), 339-344.

Marcos, B., Kerry, J. P., \& Mullen, A. M. (2010). High pressure induced changes on sarcoplasmic protein fraction and quality indicators. Meat Science, 85(1), 115-120.

McArdle, R. A., Marcos, B., Kerry, J. P., \& Mullen, A. M. (2011). Influence of HPP conditions on selected beef quality attributes and their stability during chilled storage. Meat Science, 87(3), 274-281.

McArdle, R. A., Marcos, B., Mullen, A. M., \& Kerry, J. P. (2013). Influence of HPP conditions on selected lamb quality attributes and their stability during chilled storage. Innovative Food Science \& Emerging Technologies, http://dx.doi.org/10.1016/j.ifset.2013.04.003.

McArthur, A. J., \& Wilding, P. (1996). The effect of high pressure on skeletal muscle myofibrils and myosin. In R. Hayashi \& C. Balny (Eds.), High pressure bioscience and biotechnology (pp. 323326). Amsterdam: Elsevier Science B.V.

McLoughlin, J. V., \& Goldspink, G. (1963). Post-mortem changes in the colour of pig Longissimus dorsi muscle. Nature, 198, 584-585.

Messens, W., Van Camp, J., \& Huyghebaert, A. (1997). The use of high pressure to modify the functionality of food proteins. Trends in Food Science and Technology, 8, 107-112.

Monin, G., \& Laborde, D. (1985). Water holding capacity of pig muscle proteins: Interaction between the myofibrillar proteins and sarcoplasmic compounds. Science des Aliments, 5, 341-345.

Mozhaev, V. V., Heremans, K., Frank, J., Masson, P., \& Balny, C. (1994). Exploiting the effects of high hydrostatic pressure in biotechnological applications. Tibtech, 12, 493-501.

Ohshima, T., Ushio, H., \& Koizumi, C. (1993). High-pressure processing of fish and fish products. Trends in Food Science \& Technology, 4(11), 370-375.

Picouet P, Sala X, Garcia-Gil N, Nolis P, Colleo M, Parella T, Arnau J. (2012) High pressure processing of dry-cured ham: Ultrastructural and molecular changes affecting sodium and water dynamics. Innovative Food Science and Emerging Technologies, 16, 335-340.

Pietrasik, Z., \& Shand, P. J. (2004). Effect if blade tenderization and tumbling time on the processing characteristics and tenderness of injected cooked roast beef. Meat Science, 66(4), 871-879.

Realini, C.E., Guàrdia, M.D., Garriga, M., Pérez-Juan, M., \& Arnau, J. (2011). High pressure and freezing temperature effect on quality and microbial inactivation of cured pork carpaccio. Meat Science, 88(3), 542-547.

Rivalain, N., Roquain, J., \& Demazeau, G. (2010). Development of high hydrostatic pressure in biosciences: Pressure effect on biological structures and potential applications in Biotechnologies. Biotechnology Advances, doi:10.1016/j.biotechadv.2010.04.001.

Sayd, T., Morzel, M., Chambon, C., Franck, M., Figwer, P., Larzul, C., LeRoy, P., Monin, G., Cherel, P., \& Laville, E. (2006). Proteome analysis of the sarcoplasmic fraction of pig Semimembranosus muscle: Implications on meat color development. Journal of Agricultural and Food Chemistry, 54(7), 2732-2737.

Serra, X., Grèbol, N., Guàrdia, M. D., Guerrero, L., Gou, P., Masoliver, P., Gassiot, M., Sárraga, C., Monfort, J. M., \& Arnau, J. (2007). High pressure applied to frozen ham at different process 
stages. 2. Effect on the sensory attributes and on the colour characteristics of dry-cured ham. Meat Science, 75(1), 21-28.

Shigehisa, T., Ohmori, T., Saito, A., Taji, S., \& Hayashi, R. (1991). Effects of high hydrostatic pressure on characteristics of pork slurries and inactivation of microorganisms associated with meat and meat products. International Journal of Food Microbiology, 12(2-3), 207-215.

Sikes, A., Tornberg, E., \& Tume, R. (2010). A proposed mechanism of tenderising post-rigor beef using high pressure-heat treatment. Meat Science, 84(3), 390-399.

Sikes, A. L., Tobin, A. B., \& Tume, R. K. (2009). Use of high pressure to reduce cook loss and improve texture of low-salt beef sausage batters. Innovative Food Science \& Emerging Technologies, 10(4), 405-412.

Sun, X. D., \& Holley, R. (2010). High hydrostatic pressure effects on the texture of meat and meat products. Journal of Food Science, 75(1), R17-R23.

van de Wiel, D. F. M., \& Zhang, W. L. (2007). Identification of pork quality parameters by proteomics. Meat Science, 77(1), 46-54.

van Laack, R. L. J. M., Kauffman, R. G., Sybesma, W., Smulders, F. J. M., Eikelenboom, G., \& Pinheiro, J. C. (1994). Is colour brightness (L-value) a reliable indicator of water-holding capacity in porcine muscle? Meat Science, 38(2), 193-201.

Zayas, J. F. (1997). Solubility of proteins. In J. F. Zayas (Ed.), Functionality of proteins in food (pp. 675). Berlin: Springer. 
Figure 1. Representative 2-DE gels of sarcoplasmic extracts obtained from bovine longissimus thoracis et lumborum muscle: a) non-treated and b) treated at $600 \mathrm{MPa}$. Muscle proteins with significantly different abundance among treatments are marked and numbered. See table 3 for detailed list of muscle proteins from sarcoplasmic fraction that changed in abundance due to high pressure processing.
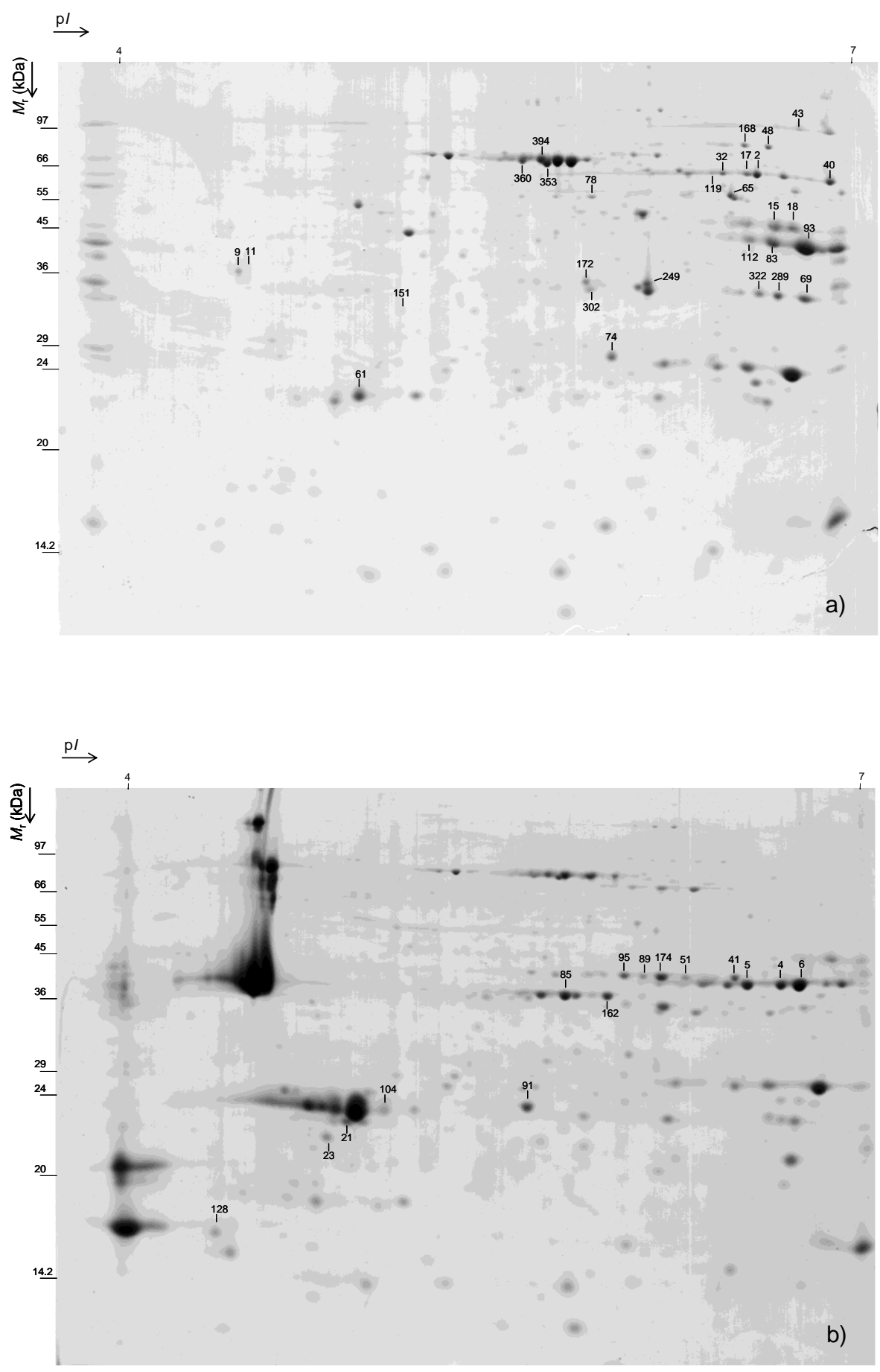
Figure 2. Representative 2-DE gels of myofibrillar extracts obtained from bovine longissimus thoracis et lumborum muscle: a) non-treated and b) treated at $600 \mathrm{MPa}$. Muscle proteins with significantly different abundance among treatments are marked and numbered. See table 4 for detailed list of muscle proteins from myofibrillar fraction that changed in abundance due to high pressure processing.
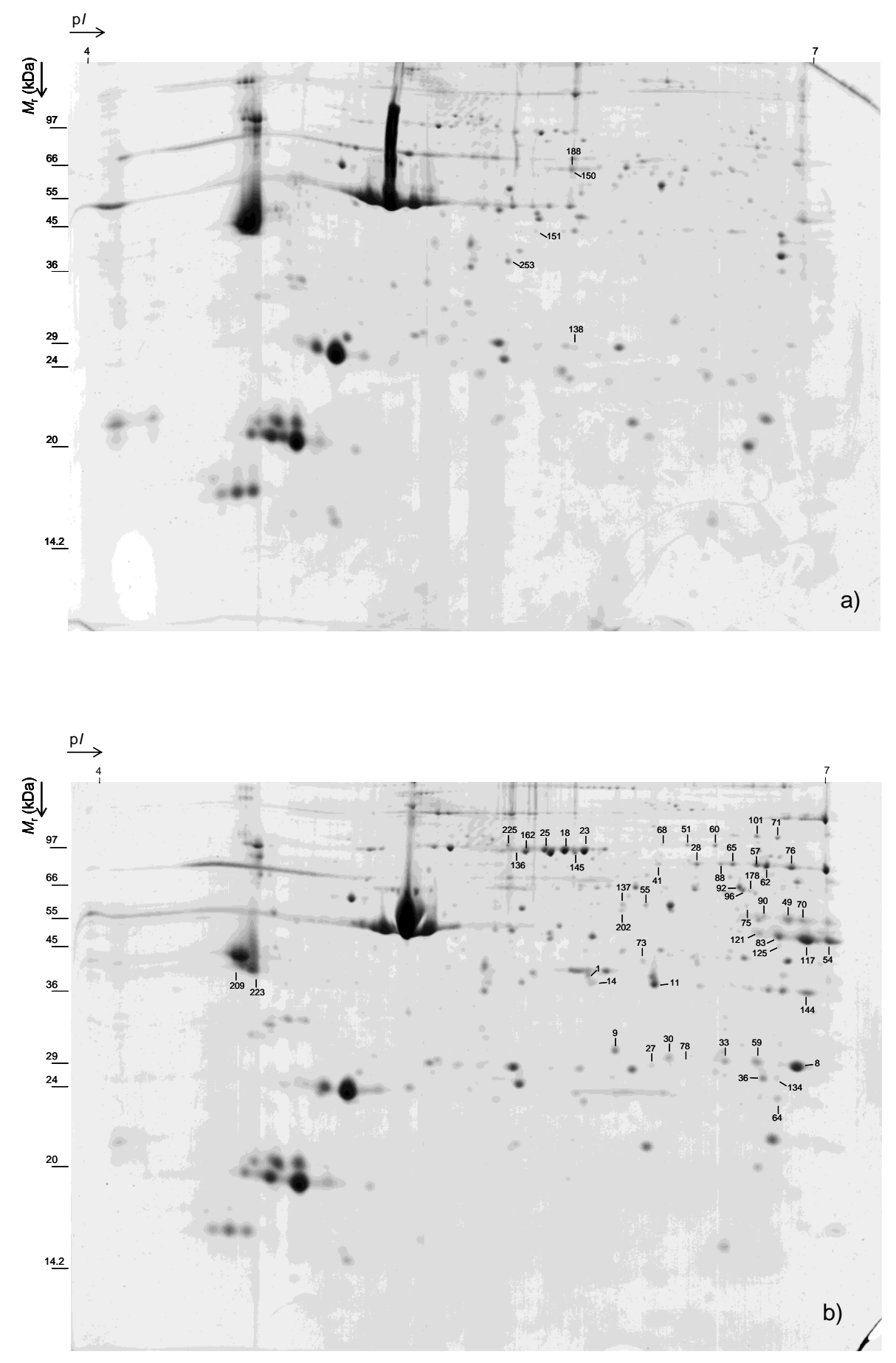
Table 1. Effect of high pressure processing on the quality parameters of longissimus thoracis et lumborum muscle.

\begin{tabular}{|c|c|c|c|c|c|c|c|c|}
\hline & \multicolumn{3}{|c|}{ Protein solubility $(\mu \mathrm{g} / \mathrm{g})$} & \multirow[b]{2}{*}{ EM } & \multirow[b]{2}{*}{$L^{*}$} & \multirow[b]{2}{*}{$a^{*}$} & \multirow[b]{2}{*}{$b^{*}$} & \multirow[b]{2}{*}{$\Delta E$} \\
\hline & total & myofibrillar & sarcoplasmic & & & & & \\
\hline NT & $99.24^{a}$ & 21.18 & $78.06^{a}$ & $21.80^{\mathrm{C}}$ & $26.07^{c}$ & 8.03 & $9.40^{b}$ & - \\
\hline $200 \mathrm{MPa}$ & $94.59^{a}$ & 22.77 & $71.82^{\mathrm{a}}$ & $22.40^{b c}$ & $33.20^{b}$ & 9.23 & $10.87^{b}$ & $7.64^{b}$ \\
\hline $400 \mathrm{MPa}$ & $65.36^{b}$ & 22.30 & $43.06^{b}$ & $30.01^{a b}$ & $55.49^{a}$ & 11.19 & $17.55^{\mathrm{a}}$ & $31.35^{\mathrm{a}}$ \\
\hline $600 \mathrm{MPa}$ & $50.56^{c}$ & 22.87 & $27.69^{c}$ & $32.72^{a}$ & $53.01^{a}$ & 8.96 & $16.41^{a}$ & $28.09^{\mathrm{a}}$ \\
\hline SE & 2.73 & 0.74 & 2.82 & 1.74 & 0.77 & 0.81 & 1.05 & 0.79 \\
\hline$p$ & $<0.001$ & NS & $<0.001$ & $<0.01$ & $<0.001$ & NS & $<0.01$ & $<0.001$ \\
\hline
\end{tabular}

Results are means of three replicates. Different letters within a column indicate differences among treatments. Total, sum of sarcoplasmic and myofibrillar protein solubility; EM, expressible moisture (\% of moisture loss); $L^{*}$, lightness; $a^{*}$, redness; $b^{*}$, yellowness; $\Delta E$, total colour difference; $\mathrm{NT}$, non-treated; $\mathrm{SE}$, standard error; NS, non-significant, $p>0.05$. 
Table 2. Correlation coefficients between quality parameters.

\begin{tabular}{|c|c|c|c|c|c|c|c|c|}
\hline & \multicolumn{3}{|c|}{ solubility } & \multirow[b]{2}{*}{$L^{*}$} & \multirow[b]{2}{*}{$a^{*}$} & \multirow[b]{2}{*}{$b^{*}$} & \multirow[b]{2}{*}{$\Delta E$} & \multirow[b]{2}{*}{ EM } \\
\hline & total & myofibrillar & sarcoplasmic & & & & & \\
\hline \multicolumn{9}{|l|}{ solubility: } \\
\hline total & 1 & -0.304 & $0.998 * * *$ & $-0.904 * * *$ & -0.303 & $-0.851 * * *$ & $-0.864 * *$ & $-0.856 * *$ \\
\hline myofibrillar & & 1 & -0.358 & 0.321 & 0.495 & 0.380 & -0.078 & 0.129 \\
\hline sarcoplasmic & & & 1 & $-0.906 * * *$ & -0.320 & $-0.856 * * *$ & $-0.859 * *$ & $-0.847 * *$ \\
\hline $\mathrm{L}^{*}$ & & & & 1 & 0.525 & $0.903^{* * *}$ & $0.999 * * *$ & $0.841 * *$ \\
\hline$a^{*}$ & & & & & 1 & $0.692^{*}$ & 0.478 & 0.430 \\
\hline$b^{*}$ & & & & & & 1 & $0.957 * * *$ & $0.767 * *$ \\
\hline$\Delta \mathrm{E}$ & & & & & & & 1 & $0.804 * *$ \\
\hline EM & & & & & & & & 1 \\
\hline
\end{tabular}

$\mathrm{L}^{*}$ : lightness; $\mathrm{a}^{*}$ : redness; $\mathrm{b}^{*}$ : yellowness; $\Delta E$ : total colour difference; $\mathrm{EM}$ : expressible moisture. Numbers marked in bold show significant correlation; ${ }^{*} p<0.05 ;{ }^{* *} p<0.01 ;{ }^{* *} p<0.001$. 
Table 3. Identification of proteins contained in the sarcoplasmic fraction which were significantly altered due to HPP.

\begin{tabular}{|c|c|c|c|c|c|c|c|c|c|c|c|c|c|}
\hline \multirow[b]{2}{*}{ Spot } & \multirow[b]{2}{*}{ Protein name } & \multirow[b]{2}{*}{$\begin{array}{l}\text { Accession } \\
\text { number }\end{array}$} & \multirow[b]{2}{*}{$\begin{array}{l}\text { Protein } \\
\text { probability }\end{array}$} & \multirow[b]{2}{*}{ Cov. $^{y}$} & \multirow[b]{2}{*}{$\begin{array}{l}\mathrm{M}_{\mathrm{W} \text { theoretical }} \\
(\mathrm{KDa})\end{array}$} & \multirow[b]{2}{*}{$\mathrm{p} /$ theoretical } & \multirow[b]{2}{*}{$\begin{array}{l}\text { matching } \\
\text { peptides }\end{array}$} & \multicolumn{6}{|c|}{ Normalised spot volume $\left(\times 10^{3}\right)$} \\
\hline & & & & & & & & NT & $\begin{array}{l}200 \\
\mathrm{MPa}\end{array}$ & $\begin{array}{l}400 \\
\mathrm{MPa}\end{array}$ & $\begin{array}{l}600 \\
\mathrm{MPa}\end{array}$ & SE & $\mathrm{p}$ \\
\hline \multicolumn{14}{|c|}{ Sarcoplasmic proteins } \\
\hline 15 & Beta-enolase & Q3ZC09 & $2.52 \mathrm{E}-10$ & 26.5 & 47.07 & 7.6 & 9 & $2153^{a}$ & $2620^{a}$ & $220^{b}$ & $268^{b}$ & 171 & $<0.001$ \\
\hline 18 & Beta-enolase & Q3ZC09 & $2.76 \mathrm{E}-10$ & 18.4 & 47.07 & 7.6 & 7 & $1994^{\mathrm{a}}$ & $2530^{\mathrm{a}}$ & $223^{b}$ & $322^{\mathrm{b}}$ & 169 & $<0.001$ \\
\hline 83 & Creatine kinase M-type & Q9Xsc6 & $1.59 \mathrm{E}-11$ & 25.2 & 42.96 & 6.7 & 7 & $9150^{\mathrm{a}}$ & $11153^{\mathrm{a}}$ & $2062^{b}$ & $2296^{b}$ & 692 & $<0.001$ \\
\hline 93 & Creatine kinase M-type & Q9XSC6 & $4.02 \mathrm{E}-10$ & 27.3 & 42.96 & 6.7 & 8 & $3804^{\mathrm{a}}$ & $4405^{\mathrm{a}}$ & $750^{\mathrm{b}}$ & $891^{b}$ & 313 & $<0.001$ \\
\hline 112 & Creatine kinase M-type & Q9XSC6 & $1.92 \mathrm{E}-10$ & 22.6 & 42.96 & 6.7 & 6 & $1839^{\mathrm{a}}$ & $2118^{a}$ & $431^{b}$ & $628^{\mathrm{b}}$ & 290 & $<0.01$ \\
\hline 78 & Cytosol aminopeptidase & P00727 & $2.76 \mathrm{E}-09$ & 45.9 & 56.25 & 6.1 & 20 & $465^{a}$ & $479^{b}$ & $559^{b}$ & $94^{\mathrm{b}}$ & 41 & $<0.001$ \\
\hline 69 & Glycerol-3-phosphate dehydrogenase [NAD+], cytoplasmic & Q5EA88 & $7.88 \mathrm{E}-14$ & 27.5 & 37.62 & 6.4 & 9 & $2307^{\mathrm{a}}$ & $547^{\mathrm{b}}$ & $366^{\mathrm{b}}$ & $397^{\mathrm{b}}$ & 74 & $<0.001$ \\
\hline 172 & Glycerol-3-phosphate dehydrogenase [NAD+], cytoplasmic & Q5EA88 & $2.78 \mathrm{E}-13$ & 22.9 & 37.62 & 6.4 & 7 & $1475^{\mathrm{a}}$ & $542^{\mathrm{b}}$ & $475^{b}$ & $399^{b}$ & 69 & $<0.001$ \\
\hline 289 & Glycerol-3-phosphate dehydrogenase $[\mathrm{NAD+}+$, cytoplasmic & Q5EA88 & $5.77 E-14$ & 42.1 & 37.62 & 6.4 & 13 & $1695^{\mathrm{a}}$ & $753^{\text {bc }}$ & $1000^{b}$ & $710^{c}$ & 59 & $<0.001$ \\
\hline 322 & Glycerol-3-phosphate dehydrogenase [NAD+], cytoplasmic & Q5EA88 & $1.89 \mathrm{E}-14$ & 42.1 & 37.62 & 6.4 & 12 & $1343^{\mathrm{a}}$ & $670^{b}$ & $702^{b}$ & $617^{\mathrm{b}}$ & 65 & $<0.001$ \\
\hline 43 & Glycogen phosphorylase, muscle form & P79334 & $2.25 \mathrm{E}-11$ & 21.9 & 97.23 & 6.6 & 14 & $438^{\mathrm{a}}$ & $92^{b}$ & $61^{\mathrm{b}}$ & $54^{\mathrm{b}}$ & 24 & $<0.001$ \\
\hline 353 & Heat shock $70 \mathrm{kDa}$ protein $1 \mathrm{~A}$ & Q27975 & $2.28 \mathrm{E}-12$ & 30.6 & 70.22 & 5.6 & 21 & $1913^{\mathrm{a}}$ & $2056^{\mathrm{a}}$ & $1705^{\mathrm{ab}}$ & $1061^{b}$ & 155 & $<0.01$ \\
\hline 360 & Heat shock $70 \mathrm{kDa}$ protein $1 \mathrm{~A}$ & Q27975 & $5.72 \mathrm{E}-13$ & 30.4 & 70.22 & 5.6 & 15 & $1106^{\mathrm{a}}$ & $1096^{\mathrm{a}}$ & $983^{a}$ & $733^{b}$ & 167 & $<0.01$ \\
\hline 249 & Malate dehydrogenase, cytoplasmic & Q3T145 & $2.33 \mathrm{E}-12$ & 32.6 & 36.42 & 6.2 & 8 & $5013^{\mathrm{a}}$ & $5218^{a}$ & $5228^{a}$ & $1898^{b}$ & 383 & $<0.001$ \\
\hline 302 & Malate dehydrogenase, cytoplasmic & Q3T145 & $1.33 \mathrm{E}-14$ & 30.8 & 36.42 & 6.2 & 8 & $1200^{\mathrm{a}}$ & $1131^{\mathrm{ab}}$ & $874^{\mathrm{b}}$ & $523^{c}$ & 70 & $<0.001$ \\
\hline 74 & Peroxiredoxin-6 & 077834 & $3.89 \mathrm{E}-08$ & 37.9 & 25.05 & 6.0 & 9 & $1581^{\mathrm{a}}$ & $1877^{\mathrm{a}}$ & $307^{\mathrm{b}}$ & $450^{b}$ & 155 & $<0.001$ \\
\hline 2 & Phosphoglucomutase-1 & Q08DP0 & $3.42 \mathrm{E}-13$ & 25.8 & 61.55 & 6.4 & 12 & $1884^{\mathrm{a}}$ & $2418^{a}$ & $109^{b}$ & $180^{\mathrm{b}}$ & 105 & $<0.001$ \\
\hline 17 & Phosphoglucomutase-1 & Q08DP0 & $4.89 \mathrm{E}-12$ & 30.2 & 61.55 & 6.4 & 11 & $978^{a}$ & $1136^{\mathrm{a}}$ & $100^{b}$ & $143^{b}$ & 96 & $<0.001$ \\
\hline 32 & Phosphoglucomutase-1 & Q08DP0 & $5.52 \mathrm{E}-11$ & 27.4 & 61.55 & 6.4 & 10 & $1310^{\mathrm{a}}$ & $1556^{\mathrm{a}}$ & $173^{b}$ & $203^{b}$ & 84 & $<0.001$ \\
\hline 40 & Phosphoglucomutase-1 & Q08DP0 & $1.78 \mathrm{E}-14$ & 42.3 & 61.55 & 6.4 & 16 & $3006^{a}$ & $2465^{\mathrm{ab}}$ & $444^{\mathrm{b}}$ & $361^{\mathrm{b}}$ & 507 & $<0.01$ \\
\hline 119 & Phosphoglucomutase-1 & Q08DP0 & $2.44 \mathrm{E}-14$ & 29.4 & 61.55 & 6.4 & 10 & $392^{\mathrm{a}}$ & $438^{a}$ & $92^{b}$ & $145^{\mathrm{b}}$ & 47 & $<0.01$ \\
\hline 151 & $\begin{array}{l}\text { Phospholysine phosphohistidine inorg. pyrophosphate } \\
\text { phosphatase }\end{array}$ & QoVD18 & $4.13 \mathrm{E}-12$ & 32.2 & 29.16 & 5.3 & 5 & $166^{a}$ & $150^{\mathrm{ab}}$ & $70^{\mathrm{bc}}$ & $41^{c}$ & 19 & $<0.01$ \\
\hline 65 & Retinal dehydrogenase 1 & P48644 & $2.44 \mathrm{E}-14$ & 32.3 & 54.77 & 6.2 & 13 & $1334^{\mathrm{a}}$ & $1424^{\mathrm{a}}$ & $1354^{\mathrm{a}}$ & $221^{\mathrm{b}}$ & 153 & $<0.01$ \\
\hline 48 & Serotransferrin & Q29443 & $2.37 E-11$ & 30.4 & 77.70 & 6.7 & 17 & $732^{\mathrm{a}}$ & $733^{\mathrm{a}}$ & $882^{\mathrm{a}}$ & $118^{\mathrm{b}}$ & 41 & $<0.001$ \\
\hline 168 & Serotransferrin & Q29443 & $1.91 \mathrm{E}-11$ & 35.6 & 77.70 & 6.7 & 18 & $763^{\mathrm{a}}$ & $798^{\mathrm{a}}$ & $951^{\mathrm{a}}$ & $252^{\mathrm{b}}$ & 77 & $<0.01$ \\
\hline 394 & Serum albumin & P02769 & $1.39 \mathrm{E}-12$ & 34.9 & 69.25 & 5.8 & 19 & $4846^{a}$ & $4794^{a}$ & $4338^{a b}$ & $2844^{b}$ & 279 & $<0.01$ \\
\hline
\end{tabular}


Myofibrillar proteins

\begin{tabular}{|c|c|c|c|c|c|c|c|c|c|c|c|c|c|}
\hline 23 & Myosin light chain 1, skeletal muscle isoform & A0JNJ5 & $6.32 \mathrm{E}-11$ & 37.5 & 20.92 & 5.0 & 6 & $157^{c}$ & $133^{c}$ & $918^{b}$ & $1318^{a}$ & 85 & $<0.001$ \\
\hline 61 & Myosin light chain 1 , skeletal muscle isoform & A0JNJ5 & $1.79 \mathrm{E}-12$ & 56.8 & 20.92 & 5.0 & 11 & $2878^{b}$ & $3598^{b}$ & $16841^{\mathrm{a}}$ & $18993^{\mathrm{a}}$ & 1220 & $<0.001$ \\
\hline 91 & Myosin light chain 1, skeletal muscle isoform & A0JNJ5 & $3.33 \mathrm{E}-15$ & 26.6 & 20.92 & 5.0 & 6 & $391^{\mathrm{b}}$ & $532^{b}$ & $1317^{\mathrm{ab}}$ & $2170^{a}$ & 237 & $<0.01$ \\
\hline 104 & Myosin light chain 1, skeletal muscle isoform & A0JNJ5 & $3.33 \mathrm{E}-16$ & 51.6 & 20.92 & 5.0 & 9 & $541^{b c}$ & $468^{c}$ & $2387^{a}$ & $1721^{a b}$ & 272 & $<0.01$ \\
\hline 11 & Tropomyosin alpha-1 chain & Q5KR49 & $1.11 \mathrm{E}-14$ & 50.7 & 32.67 & 4.5 & 17 & $1010^{b}$ & $853^{b}$ & $18356^{\mathrm{a}}$ & $27034^{\mathrm{a}}$ & 2953 & $<0.01$ \\
\hline 9 & Tropomyosin beta chain & Q5KR48 & $8.39 \mathrm{E}-10$ & 30.3 & 32.82 & 4.5 & 8 & $2387^{b}$ & $3227^{b}$ & $30130^{\mathrm{a}}$ & $35136^{\mathrm{a}}$ & 3139 & $<0.001$ \\
\hline 5 & Troponin T, fast skeletal muscle & Q8MKI3 & $6.77 \mathrm{E}-10$ & 23.2 & 32.11 & 6.0 & 7 & $106^{b}$ & $165^{b}$ & $1224^{a b}$ & $2166^{a}$ & 426 & $<0.01$ \\
\hline 41 & Troponin T, fast skeletal muscle & Q8MKI3 & $2.78 \mathrm{E}-09$ & 28.0 & 32.11 & 6.0 & 6 & $134^{\mathrm{b}}$ & $139^{b}$ & $710^{\mathrm{ab}}$ & $1104^{a}$ & 194 & $<0.01$ \\
\hline 174 & Troponin T, fast skeletal muscle & Q8MKI3 & $1.17 \mathrm{E}-09$ & 28.4 & 32.11 & 6.0 & 7 & $468^{\mathrm{b}}$ & $518^{b}$ & $1347^{a b}$ & $1721^{a}$ & 300 & $<0.05$ \\
\hline 85 & Troponin T, slow skeletal muscle & Q8MKH6 & $1.73 \mathrm{E}-07$ & 22.1 & 31.27 & 5.7 & 6 & $305^{b}$ & $390^{b}$ & $1251^{\mathrm{ab}}$ & $1767^{\mathrm{a}}$ & 292 & $<0.01$ \\
\hline 162 & Troponin T, slow skeletal muscle & Q8MKH6 & $1.65 \mathrm{E}-06$ & 21.7 & 31.27 & 5.7 & 6 & $349^{\mathrm{b}}$ & $325^{\mathrm{b}}$ & $1115^{a b}$ & $1263^{\mathrm{a}}$ & 190 & $<0.01$ \\
\hline
\end{tabular}

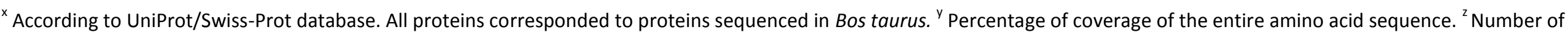
matching peptides. $\mathrm{M}_{\mathrm{w}}$ : molecular weight; $\mathrm{pl}$ : isoelecrtric point; NT: non-treated; SE: standard error; p: significance. abc: different superscripts within a row indicates differences between treatments. 
Table 4. Identification of proteins contained in the myofibrillar fraction which were significantly altered due to HPP.

\begin{tabular}{|c|c|c|c|c|c|c|c|c|c|c|c|c|c|}
\hline \multirow[b]{2}{*}{ Spot } & \multirow[b]{2}{*}{ Protein name } & \multirow[b]{2}{*}{$\begin{array}{l}\text { Accession } \\
\text { number }\end{array}$} & \multirow[b]{2}{*}{$\begin{array}{l}\text { Protein } \\
\text { probability }\end{array}$} & \multirow[b]{2}{*}{ Cov. $^{y}$} & \multirow[b]{2}{*}{$\begin{array}{l}\mathrm{M}_{\mathrm{W} \text { theoretical }} \\
(\mathrm{KDa})\end{array}$} & \multirow[b]{2}{*}{$\mathrm{p} /$ theoretical } & \multirow[b]{2}{*}{$\begin{array}{l}\text { matching } \\
\text { peptides }^{2}\end{array}$} & \multicolumn{6}{|c|}{ Normalised spot volume $\left(\times 10^{3}\right)$} \\
\hline & & & & & & & & NT & $\begin{array}{l}200 \\
\mathrm{MPa}\end{array}$ & $\begin{array}{l}400 \\
\mathrm{MPa}\end{array}$ & $\begin{array}{l}600 \\
\mathrm{MPa}\end{array}$ & SE & $p$ \\
\hline \multicolumn{14}{|c|}{ Myofibrillar proteins } \\
\hline 151 & Actin, aortic smooth muscle & P62739 & $2.40 \mathrm{E}-09$ & 16.7 & 41.98 & 5.1 & 5 & $176^{\mathrm{a}}$ & $105^{b}$ & $74^{\mathrm{b}}$ & $74^{\mathrm{b}}$ & 11 & $<0.001$ \\
\hline 253 & F-actin-capping protein subunit alpha-2 & Q5E997 & $1.53 \mathrm{E}-12$ & 46.9 & 32.96 & 5.5 & 8 & $710^{\mathrm{a}}$ & $644^{\mathrm{ab}}$ & $569^{\mathrm{bc}}$ & $525^{\mathrm{c}}$ & 19 & $<0.001$ \\
\hline 223 & Tropomyosin alpha-1 & Q5KR49 & $3.90 \mathrm{E}-11$ & 49.3 & 32.67 & 4.5 & 18 & $25472^{\text {a }}$ & $23523^{\mathrm{a}}$ & $16376^{b}$ & $15452^{b}$ & 1420 & $<0.01$ \\
\hline 209 & Tropomyosin beta chain & Q5KR48 & $1.96 \mathrm{E}-08$ & 39.4 & 32.82 & 4.5 & 13 & $13735^{\mathrm{a}}$ & $9257^{b}$ & $9241^{\mathrm{b}}$ & $7541^{b}$ & 493 & $<0.001$ \\
\hline 150 & Tubulin beta-2B chain & Q6B856 & $6.28 \mathrm{E}-09$ & 30.1 & 49.92 & 4.6 & 10 & $343^{\mathrm{a}}$ & $249^{\mathrm{ab}}$ & $143^{b}$ & $162^{b}$ & 29 & $<0.01$ \\
\hline 188 & Tubulin beta-2B chain & Q6B856 & $6.11 \mathrm{E}-10$ & 29.7 & 49.92 & 4.6 & 9 & $493^{a}$ & $411^{\mathrm{ab}}$ & $248^{\mathrm{c}}$ & $307^{\mathrm{bc}}$ & 24 & $<0.001$ \\
\hline \multicolumn{14}{|c|}{ Sarcoplasmic proteins } \\
\hline 96 & Aldehyde dehydrogenase, mitochondrial & P20000 & $2.22 \mathrm{E}-15$ & 33.1 & 56.62 & 7.5 & 13 & $132^{\mathrm{c}}$ & $145^{c}$ & $317^{b}$ & $455^{\mathrm{a}}$ & 16 & $<0.001$ \\
\hline 178 & Aldehyde dehydrogenase, mitochondrial & P20000 & $1.93 \mathrm{E}-13$ & 35.6 & 56.62 & 7.5 & 14 & $54^{\mathrm{c}}$ & $69^{\mathrm{bc}}$ & $98^{\mathrm{ab}}$ & $117^{\mathrm{a}}$ & 6 & $<0.001$ \\
\hline 75 & Alpha-enolase & Q9XSJ4 & $1.09 \mathrm{E}-11$ & 30.40 & 47.30 & 6.4 & 9 & $48^{b}$ & $33^{b}$ & $58^{b}$ & $127^{\mathrm{a}}$ & 6 & $<0.001$ \\
\hline 137 & Alpha-enolase & Q9XSJ4 & $1.19 \mathrm{E}-11$ & 23.7 & 47.30 & 6.4 & 7 & $336^{\mathrm{a}}$ & $152^{b}$ & $393^{a}$ & $358^{\mathrm{a}}$ & 18 & $<0.001$ \\
\hline 49 & Beta-enolase & Q3zC09 & $1.05 \mathrm{E}-09$ & 18.4 & 47.07 & 7.6 & 7 & $436^{\mathrm{b}}$ & $597^{b}$ & $2035^{a}$ & $1633^{a}$ & 175 & $<0.001$ \\
\hline 70 & Beta-enolase & Q3ZC09 & $2.05 \mathrm{E}-11$ & 16.1 & 47.07 & 7.6 & 6 & $400^{b}$ & $315^{b}$ & $1264^{\mathrm{a}}$ & $1169^{\mathrm{a}}$ & 105 & $<0.001$ \\
\hline 73 & Beta-enolase & Q3ZC09 & $2.30 \mathrm{E}-09$ & 12.7 & 47.07 & 7.6 & 5 & $86^{\mathrm{b}}$ & $118^{\mathrm{b}}$ & $329^{a}$ & $305^{\mathrm{a}}$ & 30 & $<0.001$ \\
\hline 90 & Beta-enolase & Q3ZC09 & $1.52 \mathrm{E}-09$ & 18.43 & 47.07 & 7.6 & 7 & $69^{b}$ & $65^{b}$ & $230^{a}$ & $223^{a}$ & 18 & $<0.001$ \\
\hline 54 & Creatine kinase M-type & Q9xsc6 & $8.44 \mathrm{E}-14$ & 31.2 & 42.96 & 6.7 & 10 & $620^{\mathrm{b}}$ & $1239^{\mathrm{b}}$ & $2798^{a}$ & $2160^{\mathrm{a}}$ & 182 & $<0.001$ \\
\hline 83 & Creatine kinase M-type & Q9XSC6 & $2.78 \mathrm{E}-13$ & 31.8 & 42.96 & 6.7 & 11 & $623^{b}$ & $832^{b}$ & $2251^{a}$ & $2261^{a}$ & 154 & $<0.001$ \\
\hline 117 & Creatine kinase M-type & Q9Xsc6 & 4.05E-09 & 25.5 & 42.96 & 6.7 & 7 & $1829^{\mathrm{b}}$ & $2379^{b}$ & $5384^{a}$ & $5357^{a}$ & 248 & $<0.001$ \\
\hline 121 & Creatine kinase M-type & Q9Xsc6 & $8.23 \mathrm{E}-10$ & 23.4 & 42.96 & 6.7 & 6 & $322^{\mathrm{b}}$ & $385^{b}$ & $851^{a}$ & $912^{\mathrm{a}}$ & 35 & $<0.001$ \\
\hline 125 & Creatine kinase M-type & Q9XSC6 & $3.46 \mathrm{E}-09$ & 30.4 & 42.96 & 6.7 & 9 & $48^{b}$ & $57^{b}$ & $127^{\mathrm{a}}$ & $132^{\mathrm{a}}$ & 13 & $<0.001$ \\
\hline 134 & Flavin reductase & P52556 & $2.62 \mathrm{E}-12$ & 36.9 & 22.12 & 6.7 & 5 & $99^{\mathrm{b}}$ & $228^{a}$ & $259^{a}$ & $259^{a}$ & 18 & $<0.001$ \\
\hline 144 & $\begin{array}{l}\text { Glycerol-3-phosphate dehydrogenase }[\mathrm{NAD}+] \text {, } \\
\text { cytoplasmic }\end{array}$ & Q5EA88 & $6.44 \mathrm{E}-14$ & 47.3 & 37.62 & 6.4 & 17 & $855^{b}$ & $1867^{\mathrm{a}}$ & $2164^{a}$ & $1914^{a}$ & 185 & $<0.01$ \\
\hline 145 & Heat shock $70 \mathrm{kDa}$ protein $1 \mathrm{~A}$ & Q27975 & $4.73 E-13$ & 32.1 & 70.22 & 5.6 & 18 & $397^{\mathrm{c}}$ & $693^{\mathrm{b}}$ & $727^{\mathrm{b}}$ & $997^{\mathrm{a}}$ & 49 & $<0.001$ \\
\hline 138 & Heat shock protein beta-1 & Q3T149 & 1.37E-09 & 31.7 & 22.38 & 6.0 & 6 & $148^{\mathrm{a}}$ & $114^{\mathrm{ab}}$ & $58^{\mathrm{b}}$ & $57^{\mathrm{b}}$ & 15 & $<0.01$ \\
\hline 1 & Malate dehydrogenase, cytoplasmic & Q3T145 & $1.58 \mathrm{E}-12$ & 22.5 & 36.42 & 6.2 & 5 & $31^{\mathrm{b}}$ & $24^{\mathrm{b}}$ & $65^{b}$ & $343^{a}$ & 24 & $<0.001$ \\
\hline 11 & Malate dehydrogenase, cytoplasmic & Q3T145 & $5.11 \mathrm{E}-14$ & 28.7 & 36.42 & 6.2 & 7 & $206^{\mathrm{b}}$ & $207^{b}$ & $303^{b}$ & $1520^{a}$ & 67 & $<0.001$ \\
\hline
\end{tabular}




\begin{tabular}{|c|c|c|c|c|c|c|c|c|c|c|c|c|}
\hline Malate dehydrogenase, cytoplasmic & Q3T145 & $6.14 \mathrm{E}-07$ & 17.7 & 36.42 & 6.2 & 5 & $79^{b}$ & $75^{b}$ & $148^{b}$ & $509^{a}$ & 18 & $<0.001$ \\
\hline Peptide methionine sulfoxide reductase & P54149 & $3.97 \mathrm{E}-13$ & 48.5 & 25.80 & 7.4 & 8 & $142^{\mathrm{b}}$ & $134^{\mathrm{b}}$ & $300^{b}$ & $683^{a}$ & 66 & $<0.01$ \\
\hline Peroxiredoxin-6 & 077834 & $9.76 \mathrm{E}-09$ & 29.0 & 25.05 & 6.0 & 7 & $118^{\mathrm{b}}$ & $168^{b}$ & $925^{a}$ & $892^{\mathrm{a}}$ & 76 & $<0.001$ \\
\hline Phosphoglucomutase-1 & Q08DP0 & $3.08 \mathrm{E}-10$ & 14.6 & 61.55 & 6.4 & 6 & $45^{b}$ & $84^{\mathrm{b}}$ & $206^{\mathrm{a}}$ & $223^{\mathrm{a}}$ & 19 & $<0.001$ \\
\hline Phosphoglucomutase-1 & Q08DP0 & $8.33 \mathrm{E}-13$ & 33.1 & 61.55 & 6.4 & 15 & $208^{\mathrm{b}}$ & $256^{\mathrm{b}}$ & $830^{\mathrm{a}}$ & $913^{\mathrm{a}}$ & 47 & $<0.001$ \\
\hline Phosphoglucomutase-1 & Q08DP0 & $1.61 \mathrm{E}-10$ & 27.9 & 61.55 & 6.4 & 11 & $181^{\mathrm{b}}$ & $186^{\mathrm{b}}$ & $690^{a}$ & $752^{\mathrm{a}}$ & 52 & $<0.001$ \\
\hline Phosphoglucomutase-1 & Q08DP0 & $1.88 \mathrm{E}-08$ & 18.3 & 61.55 & 6.4 & 8 & $113^{b}$ & $106^{\mathrm{b}}$ & $364^{\mathrm{a}}$ & $378^{\mathrm{a}}$ & 29 & $<0.001$ \\
\hline Phosphoglucomutase-1 & Q08DP0 & $5.04 \mathrm{E}-10$ & 25.3 & 61.55 & 6.4 & 10 & $134^{\mathrm{b}}$ & $122^{\mathrm{b}}$ & $639^{a}$ & $669^{\mathrm{a}}$ & 34 & $<0.001$ \\
\hline Phosphoglucomutase-1 & Q08DP0 & $2.31 \mathrm{E}-12$ & 34.9 & 61.55 & 6.4 & 16 & $374^{b}$ & $382^{b}$ & $1370^{\mathrm{a}}$ & $1622^{\mathrm{a}}$ & 110 & $<0.001$ \\
\hline Phosphoglucomutase-1 & Q08DP0 & $1.71 \mathrm{E}-11$ & 34.9 & 61.55 & 6.4 & 15 & $454^{\mathrm{b}}$ & $557^{b}$ & $1694^{a}$ & $1595^{\mathrm{a}}$ & 124 & $<0.001$ \\
\hline Protein DJ-1 & Q5E946 & $3.64 \mathrm{E}-10$ & 50.8 & 20.02 & 7.2 & 7 & $134^{\mathrm{b}}$ & $122^{b}$ & $438^{a}$ & $506^{\mathrm{a}}$ & 32 & $<0.001$ \\
\hline Rab GDP dissociation inhibitor beta & P50397 & $6.66 \mathrm{E}-15$ & 40.9 & 50.46 & 5.9 & 15 & $108^{b}$ & $94^{\mathrm{b}}$ & $128^{\mathrm{ab}}$ & $174^{\mathrm{a}}$ & 13 & $<0.01$ \\
\hline Retinal dehydrogenase 1 & P48644 & $8.02 \mathrm{E}-13$ & 45.7 & 54.77 & 6.2 & 19 & $259^{\mathrm{bc}}$ & $233^{c}$ & $481^{\mathrm{b}}$ & $823^{\mathrm{a}}$ & 53 & $<0.001$ \\
\hline Serotransferrin & Q29443 & $5.83 \mathrm{E}-11$ & 28 & 77.70 & 6.7 & 15 & $55^{b}$ & $47^{b}$ & $53^{b}$ & $217^{\mathrm{a}}$ & 22 & $<0.01$ \\
\hline Serotransferrin & Q29443 & $2.08 \mathrm{E}-10$ & 33.7 & 77.70 & 6.7 & 18 & $92^{\mathrm{b}}$ & $64^{\mathrm{b}}$ & $74^{\mathrm{b}}$ & $280^{\mathrm{a}}$ & 20 & $<0.001$ \\
\hline Serotransferrin & Q29443 & $3.46 \mathrm{E}-11$ & 26 & 77.70 & 6.7 & 14 & $18^{\mathrm{b}}$ & $17^{\mathrm{b}}$ & $18^{\mathrm{b}}$ & $67^{\mathrm{a}}$ & 8 & $<0.01$ \\
\hline Serotransferrin & Q29443 & 4.26E-13 & 36.6 & 77.70 & 6.7 & 21 & $87^{b}$ & $79^{b}$ & $83^{b}$ & $315^{\mathrm{a}}$ & 22 & $<0.001$ \\
\hline Serotransferrin & Q29443 & $1.69 \mathrm{E}-12$ & 35.5 & 77.70 & 6.7 & 21 & $104^{b}$ & $98^{\mathrm{b}}$ & $95^{\mathrm{b}}$ & $316^{\mathrm{a}}$ & 30 & $<0.01$ \\
\hline Serum albumin & P02769 & $7.98 \mathrm{E}-12$ & 50.7 & 69.25 & 5.8 & 25 & $863^{c}$ & $1017^{b c}$ & $1299^{b}$ & $1971^{\mathrm{a}}$ & 67 & $<0.001$ \\
\hline Serum albumin & P02769 & $9.73 \mathrm{E}-12$ & 58 & 69.25 & 5.8 & 32 & $374^{b}$ & $445^{b}$ & $941^{b}$ & $2471^{\mathrm{a}}$ & 186 & $<0.001$ \\
\hline Serum albumin & P02769 & $4.00 \mathrm{E}-14$ & 59.5 & 69.25 & 5.8 & 32 & $345^{b}$ & $290^{b}$ & $527^{b}$ & $1712^{\mathrm{a}}$ & 202 & $<0.001$ \\
\hline Serum albumin & P02769 & $7.55 \mathrm{E}-14$ & 55.7 & 69.25 & 5.8 & 29 & $245^{b}$ & $370^{b}$ & $644^{b}$ & $1418^{a}$ & 113 & $<0.001$ \\
\hline Serum albumin & P02769 & $8.46 \mathrm{E}-10$ & 30.3 & 69.25 & 5.8 & 15 & $91^{c}$ & $136^{\mathrm{b}}$ & $162^{\mathrm{b}}$ & $238^{\mathrm{a}}$ & 9 & $<0.001$ \\
\hline Stress-70 protein, mitochondrial & Q3ZCHO & $1.71 \mathrm{E}-12$ & 35.6 & 73.70 & 5.9 & 19 & $278^{b}$ & $254^{b}$ & $306^{b}$ & $413^{a}$ & 21 & $<0.01$ \\
\hline Triosephosphate isomerase & Q5E956 & $1.00 \mathrm{E}-30$ & 67.9 & 26.67 & 6.5 & 13 & $601^{b}$ & $567^{b}$ & $4273^{b}$ & $4547^{a}$ & 103 & $<0.001$ \\
\hline Triosephosphate isomerase & Q5E956 & $2.32 \mathrm{E}-12$ & 57.4 & 26.67 & 6.5 & 11 & $72^{b}$ & $53^{b}$ & $293^{a}$ & $217^{\mathrm{a}}$ & 24 & $<0.001$ \\
\hline Triosephosphate isomerase & Q5E956 & $6.44 \mathrm{E}-14$ & 52.6 & 26.67 & 6.5 & 10 & $116^{\mathrm{b}}$ & $129^{\mathrm{b}}$ & $576^{a}$ & $631^{\mathrm{a}}$ & 19 & $<0.001$ \\
\hline Triosephosphate isomerase & Q5E956 & $5.46 \mathrm{E}-13$ & 57.4 & 26.67 & 6.5 & 11 & $135^{\mathrm{b}}$ & $206^{b}$ & $658^{a}$ & $708^{a}$ & 34 & $<0.001$ \\
\hline Triosephosphate isomerase & Q5E956 & $2.44 \mathrm{E}-14$ & 50.6 & 26.67 & 6.5 & 11 & $260^{\mathrm{b}}$ & $262^{b}$ & $1010^{a}$ & $1143^{a}$ & 57 & $<0.001$ \\
\hline
\end{tabular}

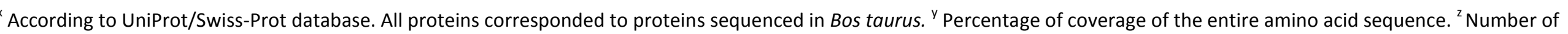

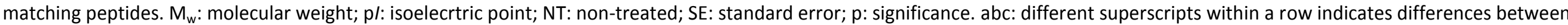
treatments. 
Table 5. Significant correlation coefficients between quality parameters and spot volume of the proteins of the sarcoplasmic fraction affected by high pressure processing.

\begin{tabular}{|c|c|c|c|c|c|c|c|}
\hline \multirow[b]{2}{*}{ Spot } & \multirow[b]{2}{*}{ Protein name } & \multicolumn{2}{|c|}{ Protein solubility } & \multirow[b]{2}{*}{$\mathrm{L}^{*}$} & \multirow[b]{2}{*}{$b^{*}$} & \multirow[b]{2}{*}{$\mathrm{AE}$} & \multirow[b]{2}{*}{ EM } \\
\hline & & total & sarcoplasmic & & & & \\
\hline \multicolumn{8}{|c|}{ Sarcoplasmic proteins } \\
\hline 15 & Beta-enolase & 0.893 & 0.887 & -0.911 & -0.919 & -0.991 & -0.833 \\
\hline 18 & Beta-enolase & 0.868 & 0.863 & -0.901 & -0.903 & -0.990 & $-0.80 \mathrm{c}$ \\
\hline 83 & Creatine kinase M-type & 0.850 & 0.842 & -0.921 & -0.864 & -0.979 & -0.843 \\
\hline 93 & Creatine kinase M-type & 0.863 & 0.857 & -0.906 & -0.898 & -0.984 & 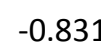 \\
\hline 112 & Creatine kinase M-type & & & -0.842 & -0.759 & -0.905 & -0.823 \\
\hline 353 & Heat shock $70 \mathrm{kDa}$ protein $1 \mathrm{~A}$ & & & & & & -0.786 \\
\hline 360 & Heat shock $70 \mathrm{kDa}$ protein $1 \mathrm{~A}$ & & & & & & -0.752 \\
\hline 74 & Peroxiredoxin-6 & 0.812 & 0.806 & -0.906 & -0.863 & -0.979 & -0.842 \\
\hline 2 & Phosphoglucomutase-1 & 0.880 & 0.869 & -0.919 & -0.838 & -0.99 & -0.853 \\
\hline 17 & Phosphoglucomutase-1 & 0.846 & 0.835 & -0.917 & -0.827 & -0.972 & -0.865 \\
\hline 32 & Phosphoglucomutase-1 & 0.852 & 0.838 & -0.883 & -0.788 & -0.989 & $-0.82 \epsilon$ \\
\hline 40 & Phosphoglucomutase-1 & 0.740 & & -0.874 & & -0.946 & -0.798 \\
\hline 119 & Phosphoglucomutase-1 & 0.765 & 0.754 & -0.875 & -0.811 & -0.927 & -0.806 \\
\hline 151 & $\begin{array}{l}\text { Phospholysine phosphohistidine inorg. pyrophosphate } \\
\text { phosphatase }\end{array}$ & 0.834 & 0.840 & -0.863 & -0.787 & -0.828 & -0.775 \\
\hline 394 & Serum albumin & 0.778 & 0.768 & & & & -0.781 \\
\hline \multicolumn{8}{|c|}{ Myofibrillar proteins } \\
\hline 23 & Myosin light chain 1 , skeletal muscle isoform & -0.944 & -0.941 & 0.886 & 0.831 & 0.862 & 0.899 \\
\hline 61 & Myosin light chain 1 , skeletal muscle isoform & -0.934 & -0.935 & 0.950 & 0.826 & 0.935 & 0.844 \\
\hline 91 & Myosin light chain 1 , skeletal muscle isoform & -0.854 & -0.856 & 0.795 & & & \\
\hline 104 & Myosin light chain 1 , skeletal muscle isoform & & & 0.854 & 0.760 & 0.844 & \\
\hline 11 & Tropomyosin alpha-1 chain & -0.921 & -0.933 & 0.914 & 0.826 & 0.918 & 0.817 \\
\hline 9 & Tropomyosin beta chain & -0.917 & -0.921 & 0.931 & 0.816 & 0.911 & 0.804 \\
\hline 5 & Troponin T, fast skeletal muscle & -0.788 & -0.785 & & & & \\
\hline 41 & Troponin T, fast skeletal muscle & -0.820 & -0.811 & 0.748 & & & 0.791 \\
\hline 174 & Troponin T, fast skeletal muscle & -0.785 & -0.784 & & & & \\
\hline 85 & Troponin T, slow skeletal muscle & -0.814 & -0.805 & 0.767 & & & 0.787 \\
\hline 162 & Troponin T, slow skeletal muscle & -0.818 & -0.807 & 0.820 & & & 0.827 \\
\hline
\end{tabular}

Only quality variables and protein peaks showing significant correlations are shown ( $<<0.006$, considering multiple testing correction as suggested by Cheverud 2001$)$. $L^{*}$ : lightness; $a^{*}$ : redness; $b^{*}$ : yellowness; $\Delta E$ : total colour difference; EM: expressible moisture. 
Table 6. Significant correlation coefficients between proteins contained in the myofibrillar fraction presenting differences among treatments and quality parameters.

\begin{tabular}{|c|c|c|c|c|c|c|c|}
\hline \multirow[b]{2}{*}{ Spot } & \multirow[b]{2}{*}{ Protein name } & \multicolumn{2}{|c|}{ Protein solubility $(\mu \mathrm{g} / \mathrm{g})$} & \multirow[b]{2}{*}{$\mathrm{L}^{*}$} & \multirow[b]{2}{*}{$b^{*}$} & \multirow[b]{2}{*}{$A E$} & \multirow[b]{2}{*}{ EM } \\
\hline & & total & sarcoplasmic & & & & \\
\hline \multicolumn{8}{|c|}{ Myofibrillar proteins } \\
\hline 151 & Actin, aortic smooth muscle & 0.751 & 0.760 & -0.827 & -0.821 & & \\
\hline 253 & F-actin-capping protein subunit alpha-2 & 0.848 & 0.854 & -0.895 & -0.816 & & -0.892 \\
\hline 223 & Tropomyosin alpha-1 & 0.845 & 0.834 & -0.907 & -0.756 & -0.845 & -0.793 \\
\hline 209 & Tropomyosin beta chain & 0.747 & 0.769 & & & & \\
\hline 150 & Tubulin beta-2B chain & 0.848 & 0.856 & -0.831 & -0.892 & & \\
\hline 188 & Tubulin beta-2B chain & 0.806 & 0.799 & -0.919 & -0.861 & -0.870 & -0.767 \\
\hline \multicolumn{8}{|c|}{ Sarcoplasmic proteins } \\
\hline 96 & Aldehyde dehydrogenase, mitochondrial & -0.959 & -0.960 & 0.872 & 0.799 & & 0.879 \\
\hline 178 & Aldehyde dehydrogenase, mitochondrial & -0.925 & -0.930 & 0.872 & 0.809 & & 0.802 \\
\hline 75 & Alpha-enolase & -0.827 & -0.823 & & & & 0.786 \\
\hline 49 & Beta-enolase & -0.794 & -0.789 & 0.93 & 0.818 & 0.908 & 0.837 \\
\hline 70 & Beta-enolase & -0.846 & -0.843 & 0.913 & 0.824 & 0.934 & 0.883 \\
\hline 73 & Beta-enolase & -0.878 & -0.871 & 0.913 & 0.914 & 0.875 & 0.813 \\
\hline 90 & Beta-enolase & -0.910 & -0.902 & 0.912 & 0.800 & 0.918 & 0.778 \\
\hline 54 & Creatine kinase M-type & 0.785 & -0.780 & 0.937 & 0.82 & 0.901 & \\
\hline 83 & Creatine kinase M-type & -0.911 & -0.905 & 0.952 & 0.826 & 0.923 & 0.883 \\
\hline 117 & Creatine kinase M-type & -0.911 & -0.905 & 0.972 & 0.850 & 0.950 & 0.887 \\
\hline 121 & Creatine kinase M-type & -0.946 & -0.944 & 0.962 & 0.871 & 0.946 & 0.906 \\
\hline 125 & Creatine kinase M-type & -0.872 & -0.867 & 0.886 & 0.882 & 0.852 & 0.754 \\
\hline 145 & Heat shock $70 \mathrm{kDa}$ protein $1 \mathrm{~A}$ & -0.803 & -0.819 & 0.768 & & & \\
\hline 1 & Malate dehydrogenase, cytoplasmic & -0.799 & -0.795 & & & & \\
\hline 11 & Malate dehydrogenase, cytoplasmic & -0.787 & -0.785 & & 0.438 & & \\
\hline 14 & Malate dehydrogenase, cytoplasmic & -0.834 & -0.834 & & 0.507 & & \\
\hline 36 & Peptide methionine sulfoxide reductase & -0.838 & -0.841 & & 0.515 & & \\
\hline 9 & Peroxiredoxin-6 & -0.898 & -0.893 & 0.953 & 0.822 & & 0.86 \\
\hline 28 & Phosphoglucomutase-1 & -0.931 & -0.932 & 0.949 & 0.875 & 0.956 & 0.831 \\
\hline 41 & Phosphoglucomutase-1 & -0.877 & -0.880 & 0.941 & 0.859 & 0.889 & 0.764 \\
\hline 57 & Phosphoglucomutase-1 & -0.961 & -0.959 & 0.948 & 0.868 & 0.929 & 0.862 \\
\hline 62 & Phosphoglucomutase-1 & -0.942 & -0.942 & 0.913 & 0.844 & 0.893 & 0.831 \\
\hline 65 & Phosphoglucomutase-1 & -0.939 & -0.939 & 0.923 & 0.870 & 0.909 & 0.824 \\
\hline
\end{tabular}




\begin{tabular}{|c|c|c|c|c|c|c|c|}
\hline 76 & Phosphoglucomutase-1 & -0.889 & -0.890 & 0.949 & 0.826 & 0.930 & 0.780 \\
\hline 88 & Phosphoglucomutase-1 & -0.917 & -0.906 & 0.926 & 0.799 & 0.921 & 0.851 \\
\hline 64 & Protein DJ-1 & -0.942 & -0.935 & 0.920 & 0.878 & 0.923 & 0.881 \\
\hline 202 & Rab GDP dissociation inhibitor beta & -0.792 & -0.784 & & & & \\
\hline 92 & Retinal dehydrogenase 1 & -0.901 & -0.894 & 0.750 & & & 0.838 \\
\hline 18 & Serum albumin & -0.855 & -0.854 & & & & 0.750 \\
\hline 23 & Serum albumin & -0.753 & -0.755 & & & & \\
\hline 25 & Serum albumin & -0.851 & -0.849 & & & & 0.776 \\
\hline 136 & Serum albumin & -0.904 & -0.913 & 0.786 & & & \\
\hline 162 & Serum albumin & -0.921 & -0.923 & 0.761 & & & 0.822 \\
\hline 225 & Stress-70 protein, mitochondrial & -0.772 & -0.765 & & & & \\
\hline 8 & Triosephosphate isomerase & -0.957 & -0.952 & 0.964 & 0.897 & 0.976 & 0.870 \\
\hline 27 & Triosephosphate isomerase & -0.792 & -0.782 & 0.891 & 0.870 & 0.916 & \\
\hline 30 & Triosephosphate isomerase & -0.950 & -0.947 & 0.967 & 0.891 & 0.972 & 0.885 \\
\hline 33 & Triosephosphate isomerase & -0.952 & -0.950 & 0.962 & 0.8903 & 0.946 & 0.881 \\
\hline 59 & Triosephosphate isomerase & -0.949 & -0.947 & 0.942 & 0.887 & 0.941 & 0.863 \\
\hline
\end{tabular}

Only quality variables and protein peaks showing significant correlations are shown ( $p<0.005$, considering multiple testing correction as suggested by Cheverud 2001$)$. $L^{*}$ : lightness; $\mathrm{a}^{*}$ : redness; $b^{*}$ : yellowness; $\Delta E$ : total colour difference; $E M$ : expressible moisture. 